\title{
Fragment-based identification of ligands for bromodomain-containing factor 3 of Trypanosoma cruzi
}

\author{
Corentine M. C. Laurin, ${ }^{1}$ Joseph P. Bluck, ${ }^{1,2}$ Anthony K. N. Chan, ${ }^{1}$ Michelle Keller, ${ }^{1}$ Andrew Boczek, ${ }^{1}$ Amy R. \\ Scorah, ${ }^{1}$ K. F. Larissa See,${ }^{1}$ Laura E. Jennings, ${ }^{1}$ David S. Hewings, ${ }^{1}$ Fern Woodhouse, ${ }^{1}$ Matthias Schiedel,,${ }^{1}$ Philip \\ G. Humphreys, ${ }^{3}$ Philip C. Biggin, ${ }^{2}$ Stuart J. Conway. ${ }^{1, *}$ \\ ${ }^{1}$ Department of Chemistry, Chemistry Research Laboratory, University of Oxford, Mansfield Road, Oxford, OX1 3TA, UK \\ ${ }^{2}$ Department of Biochemistry, 3 Parks Road, Oxford, OX1 3QU, UK \\ ${ }^{3}$ GlaxoSmithKline R\&D, Stevenage, Hertfordshire, SG1 2NY, UK
}

KEYWORDS. Chagas disease, Trypanosoma cruzi, bromodomain-containing factor 3, BI-2536, fragment-based discovery.

\begin{abstract}
The Trypanosoma cruzi (T. cruzi) parasite is the cause of Chagas disease, a neglected disease endemic in South America. The life cycle of the T. cruziparasite is complex and includes transitions between distinct life stages. This change in phenotype (without a change in genotype) could be controlled by epigenetic regulation, and might involve the bromodomain-containing factors 1-5 (TcBDF1-5). However, little is known about the function of the $T c B D F 1-5$. Here we describe a fragment-based approach to identify ligands for $T$. cruzibromodomaincontaining factor 3 ( $T \mathrm{CBDF} 3$ ). We expressed a soluble construct of $T \mathrm{CBDF} 3$ in $E$. coli, and used this to develop a range of biophysical assays for this protein. Fragment screening identified twelve compounds that bind to the TCBDF3 bromodomain. Based on this screen, we developed functional ligands containing a fluorescence or ${ }^{19} \mathrm{~F}$ reporter group, and a photo-crosslinking probe for $T C B D F 3$. These tools compounds will be invaluable in future studies on the function of $T c B D F 3$ and will provide insight into the biology of $T$. cruzi.
\end{abstract}

Introduction

Chagas disease is a life-threatening illness that is endemic to Latin America and affects 7-8 million people worldwide. Population mobility has resulted in a spread of the disease to the USA, Canada and Europe, making it a truly global problem. ${ }^{1}$ While the initial acute phase of the disease can be asymptomatic, it has the potential to be fatal. In addition, between $20 \%$ and $30 \%$ of infected patients develop irreversible cardiovascular, gastrointestinal, or neurological complications. Two treatments, nifurtimox and benznidazole, are available but they are only effective if taken during the acute phase of the disease and their mechanism of action is unknown. ${ }^{1}$ Chagas disease is caused by the protozoan parasite Trypanosoma cruzi ( $T$. cruzi), which is transmitted to mammals by hematophagous triatominae insects. ${ }^{2}$

The $T$. cruzi life cycle is complex: in tritominae insects, the parasite exists as epimastigotes and metacyclic trypomastigotes, whereas it differentiates into amastigotes and trypomastigotes in humans. Transitions between the epimastigote, trypomastigote, and amastigote forms are required for infection and replication. ${ }^{3}$ These changes in phenotype occur without alteration to the parasite DNA sequence, suggesting that epigenetic mechanisms might play a role in these processes. ${ }^{4}$

Post-translational modifications (PTMs) of histone proteins are one key mechanism that mediates epigenetic processes in humans. ${ }^{5}$ Acetylation of lysine is a heavily studied PTM that occurs not only on histones, but at 3600 sites in 1750 proteins in MV4;11, A549 and Jurkat cells. Lysine acetylation is introduced by 'writer' proteins, histone/lysine acetyl transferases (HATs/KATs), and removed by 'eraser' proteins, histones/lysine deacetylase (HDACs/KDACs). Bromodomains are 'readers' of acetylated lysine (KAc) residues. ${ }^{6-7}$

Over the past decade, there has been intense study of the role human bromodomains $^{8-10}$ play in oncology indications, leading to $>30$ clinical trials involving bromodomain ligands. In contrast, little is known about the role of non-human bromodomains. Here we present initial work towards the development of tool compounds to assist in the study of bromodomain function in $T$. cruzi.

The $T$. cruzi genome encodes for five established bromodomaincontaining protein factors (BCFs), TcBDF1-5 (Figure 1E), ${ }^{11}$ with two more recently identified: TcBDF6-7. ${ }^{12}$ TCBDF2 binds to acetylated histones and accumulates after UV irradiation; ${ }^{13}$ overexpression of wild-type TCBDF1 has effects on the epimastigote, trypomastigotes, and amastigotes life stages. ${ }^{14}$ Interestingly, $T C B D F 3$ was found in the cytoplasm, the flagellum, and the flagellar pocket and is thought to bind to $\alpha$-tubulin. While these studies are starting to elucidate the role of these proteins in the life cycle of the parasite, there is still much to learn about the functions of these proteins. Given the fundamental role played by some bromodomain-containing proteins in humans, ${ }^{15-17}$ we aimed to develop small molecule tools to help elucidate the roles of bromodomains in parasite development, replication, and survival.

While the $T c B D F 3$ bromodomain ( $\left.T c B D F 3_{32-148}, T c B D F 3-B R D\right)$ does not show high sequence identity to any of the human bromodomains we considered (data not shown), it has greater identity to the second bromodomains of the human bromodomain and extra-terminal (BET) bromodomain-containing proteins than to the first BET bromodomains. Sequence analysis revealed 22-25\% identity with BRD2-4(2) (Table SI-A1); TcBDF3 also has 65\% identity with PP-BRD20, which is a bromodomain from Trypanosoma brucei gambiense (strain MHOM/CI/86/DAL972) (Figure 1E). In fact, TCBDF3 has higher identity to PP-BRD20 than to the other bromodomains from T. cruzi (Figure SI-A1). An X-ray crystal structure of the PP-BRD20 bromodomain bound to the human bromodomain ligand BI-2536 (1) has been solved (Figure 1D, PDB code 5C8G). 


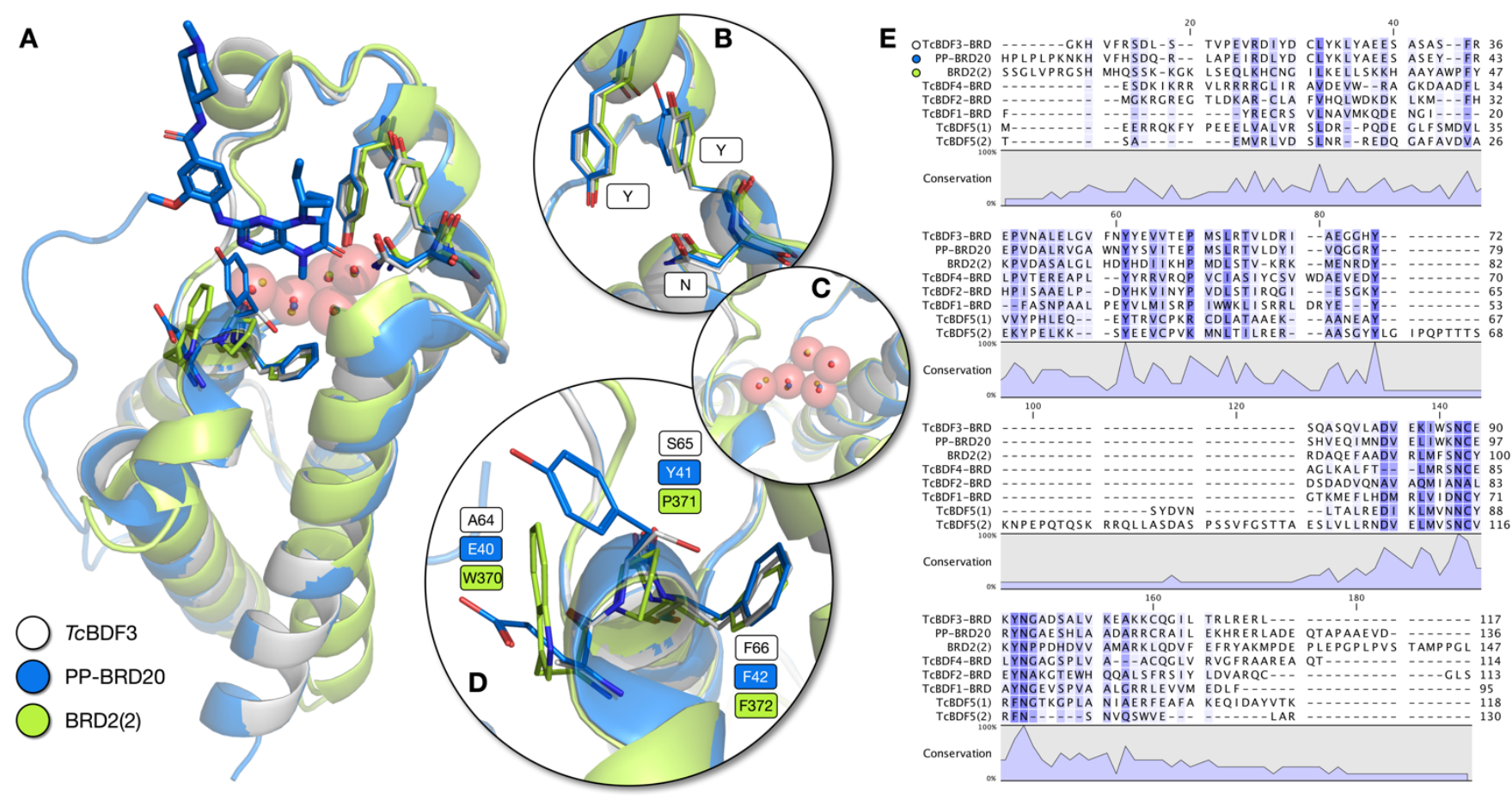

Figure 1. A. The X-ray crystal structure of pp-BRD20 (carbon = blue; PDB code 5C8G) overlaid with HmBRD2(2) (carbon = green; PDB code $4 \mathrm{UYG}$ ) and the homology model of TcBDF3 (carbon = white). This overlay shows that $(\mathbf{B})$ the key residues in KAc binding site are conserved, and that $(\mathbf{C})$ the water molecules in the KAc binding site are predicted to be the same positions as for PP-BRD20 and HmBRD2(2). D. The WPF shelf region of $H m B R D 2(2)$ is not conserved in PP-BRD20 or TcBDF3, with the residues replaced by ASF in the latter. E. The sequence alignment of the TcBDF1-5 bromodomains, PP-BRD20, and HmBRD2(2).

This provides useful structural information and indicates that ligands for human bromodomains might act as lead compounds for developing TCBDF3-BRD ligands. Taken together, these observations encouraged us to focus our investiagtions on developing ligands for the $T \mathrm{CBDF} 3-\mathrm{BRD}$.

\section{Results and discussion}

As there is currently no X-ray crystal structure of $T c B D F 3$ reported, we used Modeller (v. 9.2) ${ }^{18}$ to generate a homology model of the entire $T c B D F 3-B R D$ sequence to help guide our work. Molecular dynamics (MD) simulations predicted this model to be stable in solution (Figure 1A, see SI for details). The positions of the binding site water molecules were inferred from regions of high water occupancy during MD simulations and in analogy to T. brucei PPBRD20 (Figure 1C). The homology model (Figure 1A) predicts $T c B D F 3$ to have the same left-handed bundle of four $\alpha$-helices observed in other bromodomain structures, and an asparagine residue (N124) that we expect to bind to KAc residues (Figure 1B). The KAc-binding site was predicted to be smaller than those found in the PP-BRD20 template structure, and the human BET BRDs. One side the ZA channel is predicted to feature a flat hydrophobic wall surrounding L92 and comprising ZA loop residues. The adjacent side of the ZA channel, which makes up the "WPF shelf" in the human BET proteins, comprises the ASF residues in TcBDF3 (Figure 1D).

As the MD predicted the bromodomain construct to be stable, the full $T c B D F 3$ gene (GenBank ID: XP_812334.1) was used to clone 9 bromodomain constructs based on the sequence used in $\mathrm{MD}$, but with varying start and end points. Expression in E. coli and purification yielded a soluble protein construct: $\mathrm{H} 6-T c B D F 3_{32-148}$ (Figure SI-A). To the best of our knowledge, this is the first soluble construct reported for TCBDF3-BRD, although others have expressed the full length protein and reconstituted it from inclusion bodies. ${ }^{19}$ Analysis of the expressed protein using circular dichroism revealed a similar $\alpha$-helix signature to that observed for HmBRD4(1) (Figure SI-A4), providing confidence that the protein was folded appropriately.

\section{Fragment screen}

At the time this worked commenced, no $T c B D F 3-B R D$ ligands had been reported. Therefore, to maximise our chances of success, we took a fragment-based approach to identify ligands for TCBDF3BRD. Based on observations from our homology model, we assembled a 50-member focused library of fragments that contain known KAc mimics. The 1,3-dimethyl-1,3-dihydro- $2 H$ benzo[d]imidazol-2-one KAc mimic was included as I-BET151 (2) binds to T. brucei BDF2 through this moiety, and not the 3,5dimethylisoxazole. $^{20}$ We also included a range of 3,5dimethylisoxazole-based compounds based on $2^{21}$ and OXFBD02 (3) ${ }^{22-23}$ which have been developed into effective $\mathrm{BET}^{8-10}$ and CREBBP bromodomain ligands. ${ }^{24} \mathrm{We}$ included a selection of 5amino-4-chloro-2-methylpyridazin-3(2H)-one derivatives, which have been used as the basis to develop PCAF and GCN5 bromodomain ligands. ${ }^{25}$ Based on the X-ray crystal structure of $\mathrm{BI}$ 2536 (1) bound to PP-BRD20 (PDB code: 5C8G), we included 1, and three fragments based on its KAc mimic. We also included KAc mimics based on the BET bromodomain ligand I-BET726 (4) ${ }^{26}$ and 
the CREBBP bromodomain ligand TPOP146 (5). ${ }^{27}$ During the course of our work, Serra et al. ${ }^{28-29}$ reported 6 and 7, as ligands for TCBDF3-BRD, and so these compounds were also included. The initial fragment screen was conducted using waterLOGSY, which is a useful technique for identifying low affinity ligands and fragments, ${ }^{30}$ and does not require a previously identified binding partner for $T C B D F 3$.

We were pleased to find that 12 of the 52 tested compounds bound to the TCBDF3 bromodomain (Table 1). Fragments based on the 1,3-dimethyl-1,3-dihydro-2 $H$-benzo[d]imidazol-2-one, 3,5dimethylisoxazole, and the dihydropteridinone KAc mimics showed binding. We were surprised to note that compound 6 did not bind to the TCBDF3 bromodomain, when assessed by waterLOGSY. NMR analysis showed that compound 7 formed soluble aggregates in solution, and so its binding could not be assessed using waterLOGSY. Based on these results we selected the 3,5dimethylisoxazole- and the dihydropteridinone-based compounds for further investigation. While three of the 1,3-dimethyl-1,3dihydro-2 $H$-benzo $[d]$ imidazol-2-one-based compounds were observed to bind to the TCBDF3 bromodomain, we were concerned that there was no scope for expanding the SAR of this fragment, and so it was not progressed for further analysis.

\section{Affinity determination}

We quantified the TcBDF3-BRD affinity of 1, 2, 3 and, 8 using ${ }^{1} \mathrm{H}$ NMR ligand-observed protein titration. ${ }^{31}$ To obtain the $K_{\mathrm{d}}$ values we analysed the changes in ligand peak chemical shifts and broadening that occurred upon protein titration (Figures SI-B). Using this approach, $\mathbf{2}$ and $\mathbf{3}$ were determined to have $K_{\mathrm{d}}$ values for $T c B D F 3-B R D$ of $213 \pm 80 \mu \mathrm{M}$ and $482 \pm 27 \mu \mathrm{M}$, respectively. 1 has a $K_{\mathrm{d}}$ of $50 \pm 5 \mu \mathrm{M}$ (Table 2), while 8, which is a fragment based on the BI-2536 (1) KAc mimic, has a $K_{\mathrm{d}}$ of $366 \pm 4 \mu \mathrm{M}$. The TcBDF3BRD affinity of 3 , and the closely-related BI-6727 (53), was also investigated using ITC (Table 2 and Figure SI-D).

Table 1. Results of the waterLOGSY (WL) screening of 50 compound that contain a KAc mimic, or which have been reported to bind to TCBDF3. $\checkmark=$ compound binds; $X=$ compound does not bind; ? = unclear whether the compound binds; NS = compound insoluble at a concentration of $62.5 \mu \mathrm{M}$ in phosphate buffer and $1 \%$ DMSO.

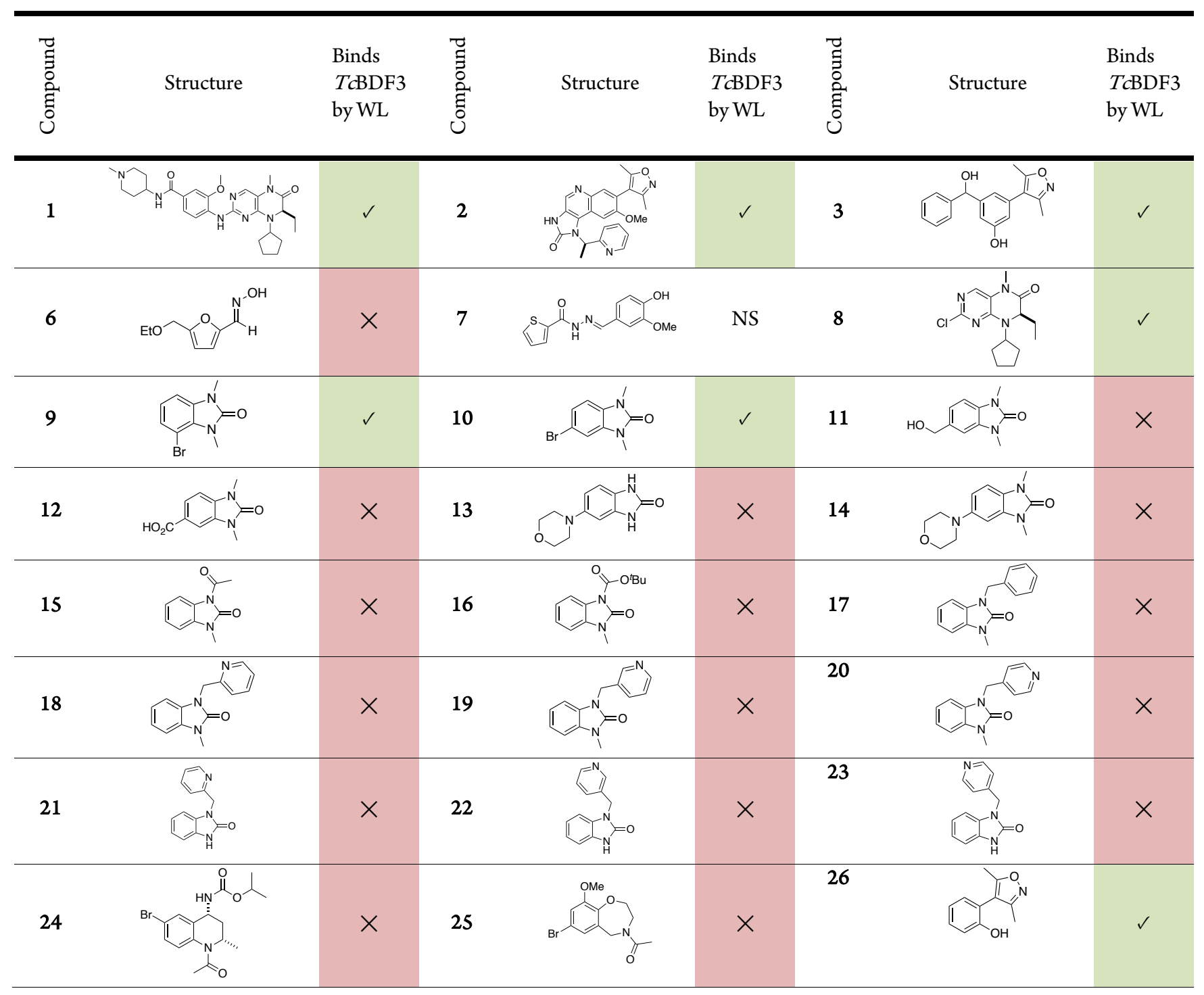




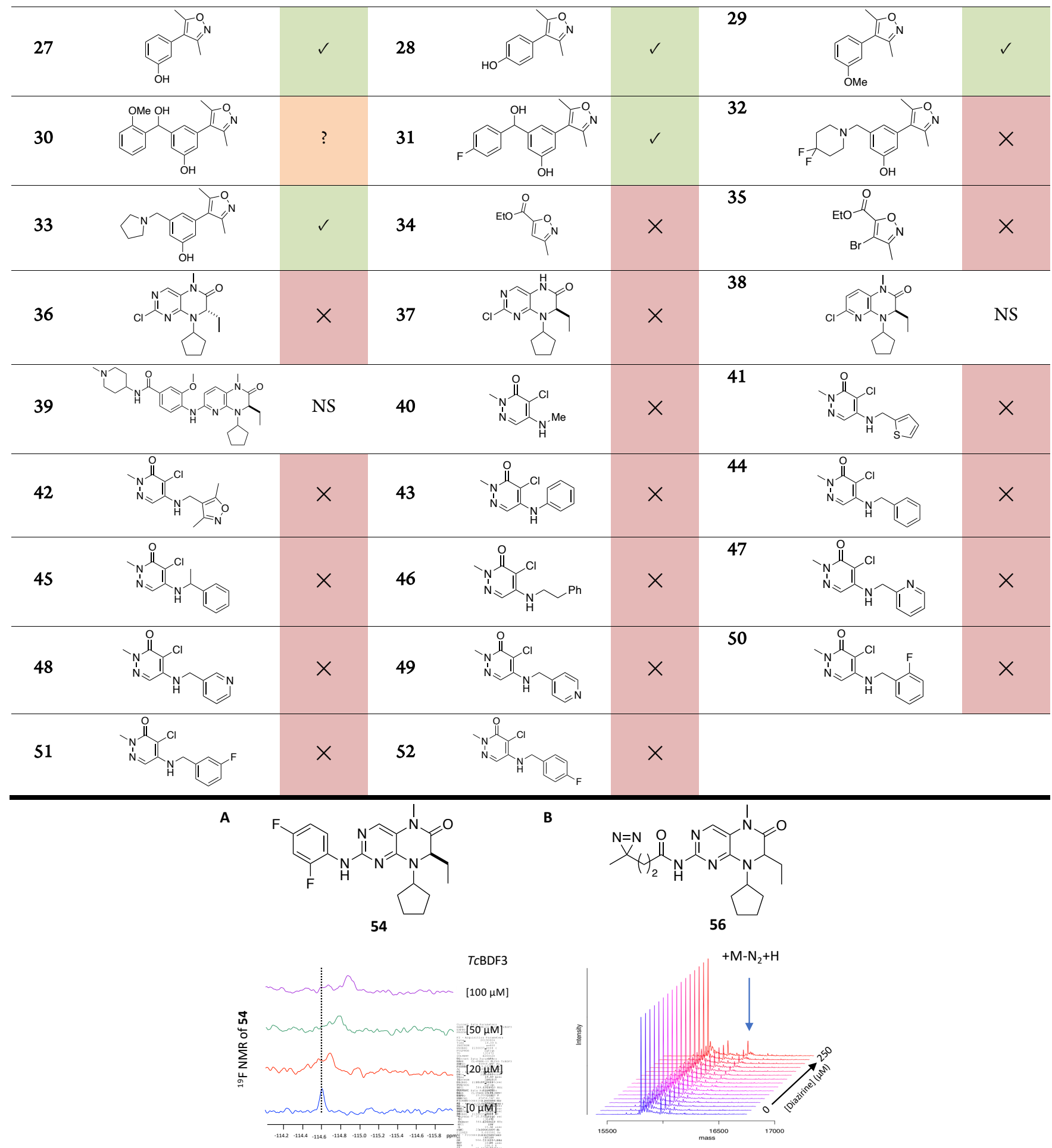

Figure 2. The $T c B D F 3$ tool compounds 54 and $\mathbf{5 6}$ bind to $T c B D F 3-B R D$ and can be used as reporter molecules in biophysical assays. A. The overlay of $564 \mathrm{MHz}{ }^{19} \mathrm{~F}$ NMR spectra showing the changes of width and chemical shift of fluorine resonances of $54(100 \mu \mathrm{M})$ in the presence of $T c B D F 3-\mathrm{BRD}$ $(20,50$, or $100 \mu \mathrm{M})$. For clarity only one of the two fluorine resonance is show, see SI-E for full spectra. B. Overlay of mass spectra showing increasing cross-linking to the protein when increasing concentrations of 56 were irradiated at $302 \mathrm{~nm}$ in the presence of $T c B D F 3-B R D$.

ITC gave a $K_{\mathrm{d}}$ value of $14.6 \pm 3.0 \mu \mathrm{M}$ for 1 , and $57.1 \pm 4.9 \mu \mathrm{M}$ for 53 . Therefore, of the compounds we tested up to this point, 1 has the highest $T c B D F 3-B R D$ affinity, and estimations of ligand efficiency (1: $\mathrm{LE}=0.16,2: \mathrm{LE}=0.16,3: \mathrm{LE}=0.21,8: \mathrm{LE}=0.24$ ) suggest that 8 provides a good starting point for developing ligands and tools to study TCBDF3-BRD. Compound 35 has one of the kinase hingebinding nitrogen atoms removed compared to 1 , and has previously been shown to have reduced PLK1 affinity (by AlphaScreen the $\mathrm{IC}_{50}$ of 35 is $263 \mathrm{nM}$ and $1870 \mathrm{nM}$, for BRD4 and PLK1, respectively). ${ }^{32}$ It is unclear whether $T c B D F 3$ possesses a PLK1 analogue, but we 
reasoned this compound might be a useful tool to help determine which protein is responsible for any phenotypic effects displayed by 1 on $T$. cruzi. Using ITC, compound 35 was shown to bind to $T c B D F 3-B R D$ with a $K_{\mathrm{d}}$ value of $18.6 \pm 8.4 \mu \mathrm{M}$ (vide infra). In contrast, the previously reported TcBDF3-BRD ligands 6 and 7 showed no detectable binding by ITC. The binding of these compounds was previously detected using a tryptophan fluorescence assay using W117. ${ }^{29}$ While the homology model predicts this residue to be close to the KAc binding pocket, it is not predicted to inteface directly with the inside of the pocket. It is possible that these compounds bind to the KAc-binding pocket and affect W117 fluorescence via allosteric actions. ${ }^{33}$ However, it is also possible that these compounds bind to another pocket that is closer to W117, which is present in the full construct of the protein used by García et al., but which is not present in our truncated soluble construct. This would explain their lack of affinity in our hands.

The ligand efficiencies of $\mathbf{1}$ and $\mathbf{8}$ suggest that the KAc mimic makes a significant contribution to the TCBDF3-BRD affinity of both these compounds. Additionally, the tail of $\mathbf{1}$ is predicted not to form any key interactions by MD simulations. Therefore, we proposed to develop probes for $T$ CBDF3-BRD by substituting the 2-chloro position of $\mathbf{8}$ with functional handles.

With the aim of developing higher-throughput assays for TcBDF3$\mathrm{BRD}$, we designed two fluorine-containing compounds, 54 and $\mathbf{5 5}$, based on the 8 headgroup, for which we investigated for use in ${ }^{19} \mathrm{~F}$ NMR-based detection of TCBDF3-BRD binding. We also designed two diazirine-containing compounds, 56 and 57, based on $\mathbf{1}$ and 8 , respectively, with a view to using them in mass spectrometry-based assays. Finally, based on $\mathbf{1}$ we designed a fluorescent probe $\mathbf{5 8}$ to use in fluorescence polarisation (FP) experiments. The syntheses of the functional probes are shown in Scheme 1, and full details are porvided in the supplementary information.

\section{${ }^{19} \mathrm{~F}$ NMR-based probes for $T \mathrm{cBDF} 3-\mathrm{BRD}$}

To develop fluorine-containing probes for TcBDF3-BRD, compounds $\mathbf{5 4}$ and $\mathbf{5 5}$ were synthesised. These molecules contain the fragment 8 coupled to a fluorine-containing substituent. Using ITC, $\mathbf{5 4}$ and $\mathbf{5 5}$ were demonstrated to bind TCBDF3-BRD with $K_{\mathrm{d}}$ values of $62.4 \pm 96.7 \mu \mathrm{M}$ and $70.8 \pm 145 \mu \mathrm{M}$, respectively. Upon titration with $20-100 \mu \mathrm{M}$ of $T c B D F 3-B R D$ the ${ }^{19} \mathrm{~F}$ chemical shifts of both 54 and 55 both moved and broadened (Figure 2 and SI-E). The effects were more pronounced for 54, perhaps as a result of the two fluorine atoms being in closer contact with the protein. These data show that $\mathbf{5 4}$ is a useful ${ }^{19} \mathrm{~F}$ NMR probe for use in displacement studies of putative TCBDF3-BRD ligands.

\section{Photo-crosslinking probes for TCBDF3-BRD}

To investigate photo-affinity crosslinking probes for $T c B D F 3-B R D$, we designed two compounds, 56 and 57, which incorporate a diazirine group. While there are a range of photo-crosslinking groups available, this group generally provides efficient crosslinking when irradiated with light of $\sim 302 \mathrm{~nm}$ wavelength. ${ }^{34}$ Compound 56 comprises the fragment $\mathbf{8}$ coupled directly to a diazirine-containing linker. 57 consists of the same linker attached to the piperidine ring of $\mathbf{1}$. The ability of $\mathbf{5 6}$ and $\mathbf{5 7}$ to photo-crosslink to TCBDF3-BRD was assessed by incubating increasing concentration of each compound with the protein. As the diazirine concentration was increased more crosslinking was observed until a plateau was reached, indicating that the protein has been saturated with diazirine. We have characterised the diazirines by the concentration at which they reach $50 \%$ of their maximum cross-linking effect, which we have defined as $\mathrm{XL}_{50}$. The $\mathrm{XL}_{50}$ values of $\mathbf{5 6}$ and $\mathbf{5 7}$ were determined by titrating the compounds into a fixed concentration of $T C B D F 3-B R D$ and irradiating for $10 \mathrm{mins}$ at a wavelength of $305 \mathrm{~nm}$. The $\mathrm{XL}_{50}$ values is $8.2 \pm 1.9 \mu \mathrm{M}$ for 56 and $14.5 \pm 3.9 \mu \mathrm{M}$ for 57 (Figure 2 and SI-G). At the highest tested concentration, 56 showed maximum cross-linking yield of $17 \%$, whereas 57 yielded $8 \%$ of cross-linked protein. The $\mathrm{XL}_{50}$ value, and the percentage crosslinking yield, result from a combination of the non-covalent affinity of the ligand and its ability to covalently link to the protein upon irradiation. While $\mathbf{5 7}$ is based on a scaffold that has higher affinity for TCBDF3-BRD than the scaffold of 56, the smaller diazirine shows greater crosslinking to the protein. This likely arises from the position of the diazirine, which is thought to be solvent exposed in the case of $\mathbf{5 7}$, whereas it is predicted to be closer to the protein surface for $\mathbf{5 6}$. These probes could be used in a competition assay to identify $T c B D F 3-B R D$ ligands that prevent the crosslinking of 56 or 57 to the protein.

\section{A fluorescent probe for TcBDF3-BRD}

The acetylated analog of $\mathbf{1}$, compound 59 (Table 2 and Scheme 1), has a $K_{\mathrm{d}}$ value of $15.9 \pm 8.4 \mu \mathrm{M}$ for $T c B D F 3-B R D$, which is very similar to that of 1 . Interestingly, the enantiomer, 60 , showed no binding indicating a specific interaction with $T c B D F 3-B R D$. These results suggest that $N$-acetylation is a feasible method of attaching substituents to the scaffold of 1 . Addition of Alexafluor488 to the piperidine ring of 1 , through acetylation, gave compound 58. The serial dilution of fluorescent probe $\mathbf{5 8}$ displayed suitable concentration-dependent fluorescent intensity (FI). Additionally, the probe showed stable fluorescent polarisation (FP) at concentrations above $20 \mathrm{nM}$ (Figure SI-F). Using FP, $\mathbf{5 8}$ was shown to bind $\mathrm{H}_{6}-T c B D F 3-\mathrm{BRD}$ with a $K_{\mathrm{d}}$ value of $3.9 \pm 1.2 \mu \mathrm{M}$ and have an assay window of approximatively $80 \mathrm{mP}$ (see SI-F). These data indicate that $\mathbf{5 8}$ could be used in a fluorescence polarisation (FP) assay to screen for ligands for $T c B D F 3$. Using FP we also showed that 58 binds to $H m B R D 4(1), H m B R D 4(2)$, and the human kinase PLK1 with $K_{\mathrm{d}}$ values of $9.9 \pm 2.5 \mathrm{nM}, 14.9 \pm 1.7 \mathrm{nM}$, and $5.5 \pm 1.5 \mathrm{nM}$, respectively (see SI-F for details).

\section{Conclusions}

We have expressed a soluble construct of the TcBDF3 bromodomain and used this protein in a range of biophysical assays to identify ligands for TcBDF3-BRD. The human dual bromodomain ligand and kinase inhibitor, BI-2536 (1), was identified as a TCBDF3-BRD ligand, and the basis for the ligand efficient $T c B D F 3-B R D$-fragment 8 . We were surprised to find that compounds 6 and 7, which have been previsouly been reported as ligand for TCBDF3 showed no binding in our hands. Fragment 8 forms the basis for a number of functional TcBDF3-BRD ligands that underpin a range of orthogonal biophysical assays for the identification of further TCBDF3-BRD ligands. These molecules will ultimately provide useful chemical tools to study the phenotype of $T c B D F-B R D 3$ inhibition in the T. cruzi parasite. 
Table 2. Quantitative affinity measurements of key compounds on $T c B D F 3-B R D, H m B R D 4(1)$ and $H m P L K 1$ obtained using NMR, ITC or FP, as stated. N.B. : no binding detected

\begin{tabular}{|c|c|c|c|c|}
\hline Compound & Structure & $\begin{array}{c}T c B D F 3-B R D K_{d} \\
(\mu \mathrm{M})\end{array}$ & $\begin{array}{c}H m B R D 4(1) K_{\mathrm{d}} \\
(\mu \mathrm{M})\end{array}$ & $\begin{array}{c}H m P L K 1 K_{\mathrm{d}} \\
(\mu \mathrm{M})\end{array}$ \\
\hline BI-2536 (1) & & $\begin{array}{c}50 \pm 5(\mathrm{NMR}, \mathrm{n}=2) \\
14.6 \pm 3.0(\mathrm{ITC}, \mathrm{n}=3) \\
(\mathrm{LE}=0.16-0.18)\end{array}$ & $\begin{array}{c}0.037 \pm 0.003 \\
\quad(\text { ITC })^{35}\end{array}$ & $0.00083\left(\mathrm{IC}_{50}\right)^{36}$ \\
\hline I-BET151 (2) & & $\begin{array}{c}232 \pm 80(\mathrm{NMR}, \mathrm{n}=2) \\
(\mathrm{LE}=0.16)\end{array}$ & $6.1 \pm 0.22(\mathrm{FP})^{37}$ & \\
\hline $\begin{array}{l}\text { OXFBD02 } \\
\text { (3) }\end{array}$ & & $\begin{array}{c}482 \pm 27(\mathrm{NMR}, \mathrm{n}=2) \\
(\mathrm{LE}=0.21)\end{array}$ & $\begin{array}{c}0.384 \\
(\text { Alpha Screen })^{23}\end{array}$ & \\
\hline 6 & & N.B. (ITC) & & \\
\hline 7 & & N.B. (ITC) & & \\
\hline 8 & & $\begin{array}{c}366 \pm 4(\mathrm{NMR}, \mathrm{n}=1) \\
(\mathrm{LE}=0.24)\end{array}$ & & \\
\hline 39 & & $\begin{array}{c}18.6 \pm 8.4(\text { ITC, } n=2) \\
\quad(\mathrm{LE}=0.18)\end{array}$ & $\begin{array}{c}0.263 \\
(\text { Alpha Screen })^{32}\end{array}$ & $\begin{array}{c}1.870 \\
(\text { Alpha Screen })^{32}\end{array}$ \\
\hline BI-6727 (53) & & $\begin{array}{c}57.1 \pm 4.9(\text { ITC, } \mathrm{n}=3) \\
(\mathrm{LE}=0.13)\end{array}$ & $0.079 \pm 0.003(\text { ITC })^{35}$ & $0.00087\left(\mathrm{IC}_{50}\right)^{38}$ \\
\hline 54 & & $\begin{array}{c}62.4 \pm 96.7(\mathrm{ITC}, \mathrm{n}=1) \\
(\mathrm{LE}=0.21)\end{array}$ & & \\
\hline 55 & & $\begin{array}{c}70.8 \pm 145(\mathrm{ITC}, \mathrm{n}=1) \\
(\mathrm{LE}=0.18)\end{array}$ & & \\
\hline 56 & & $\begin{array}{c}253 \pm 8(\mathrm{NMR}, \mathrm{n}=1) \\
(\mathrm{LE}=0.18)\end{array}$ & & \\
\hline 58 & & $\begin{array}{c}3.9 \pm 1.2(\mathrm{FP}, \mathrm{n}=2) \\
(\mathrm{LE}=0.11)\end{array}$ & $\begin{array}{c}0.0099 \pm 0.0025 \\
\quad(\mathrm{FP}, \mathrm{n}=3)\end{array}$ & $\begin{array}{c}0.0055 \pm 0.0015 \\
\quad(\mathrm{FP}, \mathrm{n}=2)\end{array}$ \\
\hline 59 & & $15.9 \pm 8.4(\mathrm{ITC}, \mathrm{n}=1)$ & & \\
\hline 60 & & N.B. (ITC) & & \\
\hline
\end{tabular}


A<smiles>[CH2]NC(CC)C(=O)OC</smiles>

61<smiles>CCC(NC1CCC(=O)C1)C(=O)OC</smiles><smiles>CC#CCC(C(=O)OC)N(c1nc(Cl)ncc1[N+](=O)[O-])C1CCCC1</smiles><smiles></smiles><smiles></smiles>

$\downarrow$<smiles>CCC1C(=O)N(C)c2cnc(Nc3ccc(C(=O)NC4CCNCC4)cc3OC)nc2N1C1CCCC1</smiles>
vi<smiles>CCC1C(=O)N(C)c2cnc(Nc3ccc(C(=O)NC4CCN(C(=O)OC(C)(C)C)CC4)cc3OC)nc2N1C1CCCC1</smiles>

B
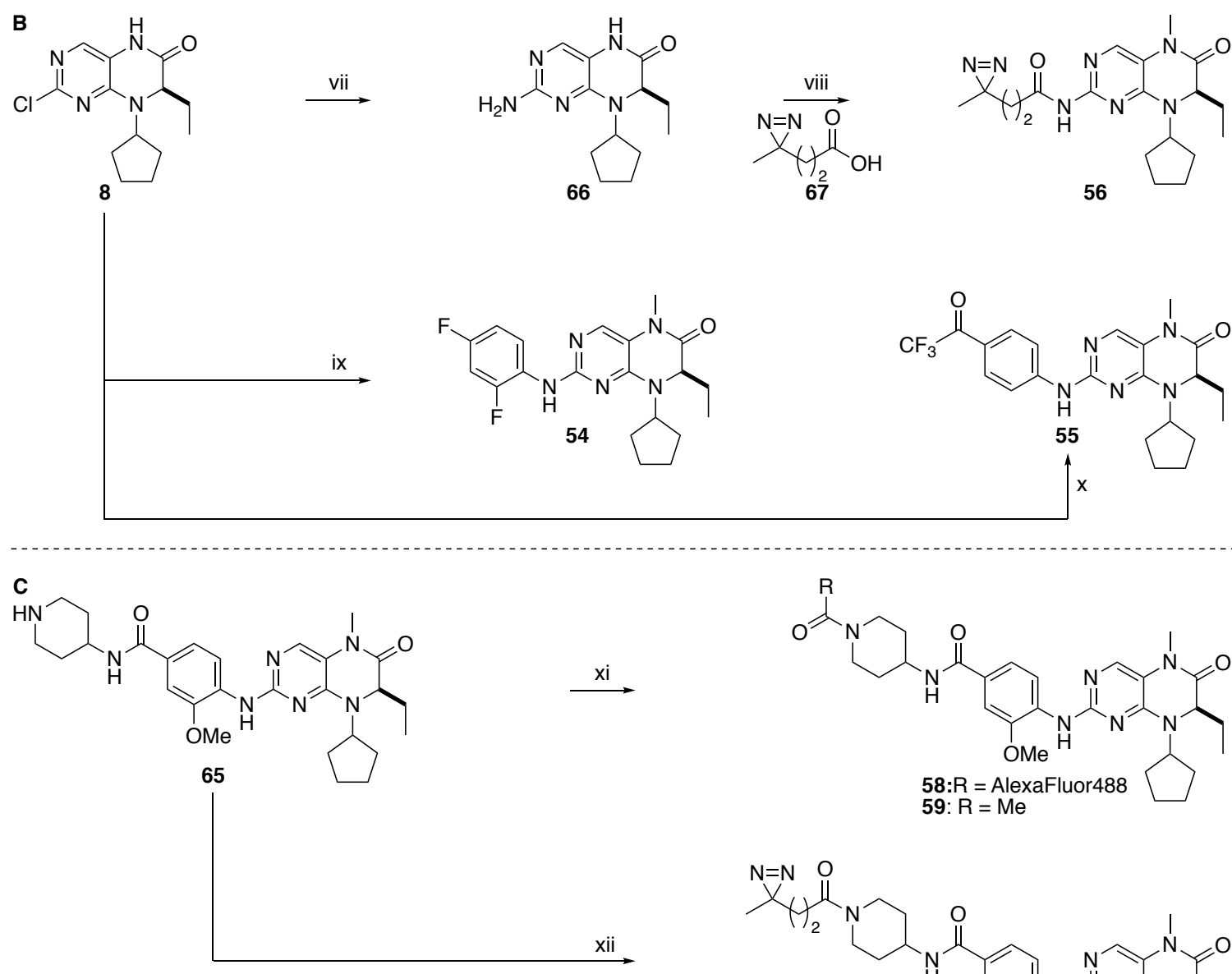<smiles>CCC1C(=O)N(C)c2cnc(Nc3ccc(C(=O)NC4CCN(C(=O)P)CC4)cc3OC)nc2N1C1CCCC1</smiles><smiles></smiles>

Scheme 1. Synthesis of fragment 8 and tool compounds for TcBDF3. Reagents and conditions: A. i. NEt 3 , Ga(OTf) $)_{3}, \mathrm{DCE}, \mathrm{RT}, 16 \mathrm{~h}, 65-78 \%$ $(\mathrm{n}=2)$; ii. 2,4-Dichloro-5-nitropyrimidine, $\mathrm{NaHCO}_{3}$, cyclohexane, RT then $60{ }^{\circ} \mathrm{C}, 3 \mathrm{~d}, 51 \%(\mathrm{n}=1)$; iii. Glacial acetic acid, $70{ }^{\circ} \mathrm{C}$ then Fe (activated), $70{ }^{\circ} \mathrm{C}$, $1 \mathrm{~h}$, then $100^{\circ} \mathrm{C}, 4 \mathrm{~h}, 61-81 \%(\mathrm{n}=3)$; iv. MeI, DMF then $\mathrm{NaH},-10^{\circ} \mathrm{C}$ then $\mathrm{RT}, 1 \mathrm{~h}, 90-98 \%(\mathrm{n}=3)$ or $\mathrm{K}_{2} \mathrm{CO}, \mathrm{MeI}, \mathrm{DMF}$, RT, 3 d, 45\% (n=1); v. (a) 4-Amino-3-methoxybenzoic acid, $\mathrm{HCl}, \mathrm{H}_{2} \mathrm{O} / \mathrm{EtOH}$ 5:1, $100{ }^{\circ} \mathrm{C}, 24 \mathrm{~h}$ (b) HBTU, DIPA, 1-Boc-4-aminopiperidine, RT, 4 h, 53\% (over 2 steps); vi. TFA, $\mathrm{CH}_{2} \mathrm{Cl}_{2}, 0^{\circ} \mathrm{C}, 1 \mathrm{~h}, 36-71 \%$, n=3. B. vii. $\mathrm{NH}_{4} \mathrm{OH} / \mathrm{IPA}=4: 1,160-170{ }^{\circ} \mathrm{C}, 6 \mathrm{~h}, \mathrm{MW}, 80 \%$ (n=2); viii. $\mathrm{HATU}$, DIPEA, $\mathrm{CH}_{2} \mathrm{Cl}_{2}$, RT, 3 h, 58\% (n=1); ix. $\mathrm{HCl}, \mathrm{EtOH} / \mathrm{H}_{2} \mathrm{O}, 2$-4-difluoronaniline, 18 h, $100^{\circ} \mathrm{C},>99 \%(\mathrm{n}=1) ; \mathrm{x} . \mathrm{HCl}, \mathrm{EtOH} / \mathrm{H}_{2} \mathrm{O}$, (trifluoroacetyl)aniline, $18 \mathrm{~h}, 100^{\circ} \mathrm{C}, 28 \%(\mathrm{n}=1)$. C. xi. $\mathrm{R}=\mathrm{Ac}$ : $\mathrm{AcCl}, \mathrm{CH}_{2} \mathrm{Cl}_{2}, 0{ }^{\circ} \mathrm{C}, 1 \mathrm{~h}, 40 \%$; $\mathrm{R}=$ AlexaFluor488: AlexaFluor488-NHS, DIPEA, DMF, RT, 18 h, RT, 61\%; xii. 63, HATU, DIPEA, $\mathrm{CH}_{2} \mathrm{Cl}_{2}, \mathrm{RT}, 3 \mathrm{~h}, 53 \%(\mathrm{n}=1)$. 
Experimental section

General experimental procedures and procedures and characterisation for intermediate compounds can be found in the SI.

( $R$ )-2-Chloro-8-cyclopentyl-7-ethyl-5-methyl-7,8-dihydropteridin6(5H)-one $(8)$

MeI ( $10 \mu \mathrm{L}, 0.14 \mathrm{mmol}, 2.0$ eq. $)$ was added to a solution of $(R)-2$ chloro-8-cyclopentyl-7-ethyl-7,8-dihydropteridin-6(5H)-one (34) $(20 \mathrm{mg}, 0.071 \mathrm{mmol}, 1.0 \mathrm{eq}$.) in dry DMF $(0.5 \mathrm{~mL})$. The reaction mixture was cooled to $-10{ }^{\circ} \mathrm{C}$ using a $\mathrm{NaCl}$ and ice bath, then $\mathrm{NaH}$ (3.5 mg, $0.14 \mathrm{mmol}, 2.0$ eq.) was added. The reaction mixture was stirred at $-10^{\circ} \mathrm{C}$ for $1 \mathrm{~h}$, then was warmed to room temperature and stirred for $1 \mathrm{~h}$. The mixture was quenched with the addition of crushed ice, then was diluted with $\mathrm{H}_{2} \mathrm{O}(20 \mathrm{~mL})$ and extracted with EtOAc $(2 \times 35 \mathrm{~mL})$. The combined organic components were washed with aq. $\mathrm{LiCl}(10 \% \mathrm{w} / \mathrm{v}, 6 \times 25 \mathrm{~mL})$, dried over $\mathrm{MgSO}_{4}$, filtered, and concentrated in vacuo. Purification by silica gel chromatography, eluting with petroleum ether:EtOAc (1:0 to $0: 1)$, afforded $\quad(R)$-2-chloro-8-cyclopentyl-7-ethyl-5-methyl-7,8dihydropteridin-6(5H)-one (8) $(21 \mathrm{mg}, 98 \%)$ as a colourless solid: $R_{f} 0.56$ (petroleum ether:EtOAc $\left.=1: 1\right) ;[\alpha]_{D}^{25}:-80.0$ (c 1.0, $\mathrm{MeOH})\left[\operatorname{lit}^{39}[\alpha]_{D}^{21.4}:-88.3(c 1.0, \mathrm{MeOH})\right] ; \tilde{\mathrm{V}}_{\max }($ thin film $) / \mathrm{cm}^{-1}$ 2968 (w), 1682 (s) (C=O), 1578 (m), 1409 (m), 1185 (m), 1058 (m); m.p. 82-84 ${ }^{\circ} \mathrm{C}$ (EtOAc) [lit. ${ }^{40} 94{ }^{\circ} \mathrm{C}$ (EtOAc)]; ${ }^{1} \mathrm{H}$ NMR $\left(400 \mathrm{MHz}, \mathrm{CDCl}_{3}\right) \delta 7.66(1 \mathrm{H}, \mathrm{s}), 4.41-4.28(1 \mathrm{H}, \mathrm{m}), 4.24(1 \mathrm{H}$, dd, J7.5, 3.6), $3.32(3 \mathrm{H}, \mathrm{s}), 2.13-2.02(1 \mathrm{H}, \mathrm{m}), 2.02-1.80(4 \mathrm{H}$, m), 1.80-1.60 (5 H, m), 0.86 (3 H, dd, J7.5, 7.5); ${ }^{13} \mathrm{C}$ NMR (101 $\left.\mathrm{MHz}, \mathrm{CDCl}_{3}\right) \delta 163.9,154.1,152.5,138.1,121.4,60.9,59.6,29.6$, 29.4, 28.4, 27.5, 24.2, 23.9, 9.2; LRMS $m / z\left(\mathrm{ES}^{+}\right) 295\left(\left[\mathrm{M}^{35} \mathrm{Cl}+\mathrm{H}\right]^{+}\right.$, $100 \%)$; Analytical HPLC (RP, method A) rt 10.17 mins, purity > 99\%. Chiral HPLC (AD-H, Hexane:IPA $=90: 10,1.0 \mathrm{~mL} / \mathrm{min}$, 20 mins) minor rt 7.74 mins, $2.5 \%$, major rt 10.18 mins, $97.5 \%$. The ${ }^{1} \mathrm{H}$ spectroscopic data are in good agreement with the literature. ${ }^{39,40}$ tert-Butyl (7R)-4-(4'-((8-cyclopentyl-7-ethyl-5-methyl-6-oxo5,6,7,8-tetrahydropteridin-2-yl)amino)-3'-

methoxybenzamido)piperidine-1-carboxylate (64)

Conc. $\mathrm{HCl}(0.51 \mathrm{~mL}, 16.6 \mathrm{mmol}, 10.0$ eq. $)$ was added to a suspension of 8 (700 mg, $1.66 \mathrm{mmol}, 1.00 \mathrm{eq}$.$) and 4-amino-3-$ methoxybenzoic acid ( $420 \mathrm{mg}, 2.49 \mathrm{mmol}, 1.50$ eq.) in $\mathrm{H}_{2} \mathrm{O}$ $(4.8 \mathrm{~mL})$ and $\mathrm{EtOH}(1.2 \mathrm{~mL})$. The mixture was stirred at $100^{\circ} \mathrm{C}$ for $20 \mathrm{~h}$, then the reaction mixture was concentrated in vacuo. The residue was dissolved in DMF $(12 \mathrm{~mL})$, then diisopropylamine (0.47 mL, $3.32 \mathrm{mmol}, 2.00$ eq.) and HBTU (1.01 g, $2.66 \mathrm{mmol}$, 1.60 eq.) were added. The reaction was stirred at room temperature for $2 \mathrm{~h}$, then tert-butyl 4-aminopiperidine-1-carboxylate $(566 \mathrm{mg}$, $2.83 \mathrm{mmol}, 1.70$ eq.) was added. After $2 \mathrm{~h}$, no conversion was observed. HBTU ( $316 \mathrm{mg}, 0.831 \mathrm{mmol}, 0.50$ eq.) was added, and the mixture was stirred at room temperature for $18 \mathrm{~h}$. Diisopropylamine ( $1.19 \mathrm{~mL}, 8.31 \mathrm{mmol}, 5.00$ eq.) and tert-butyl 4aminopiperidine-1-carboxylate (64) (333 mg, $1.66 \mathrm{mmol}, 1.00 \mathrm{eq}$.) were added, and the reaction mixture was stirred for $2 \mathrm{~h}$, then diluted with $\mathrm{H}_{2} \mathrm{O}(100 \mathrm{~mL})$ and extracted with EtOAc $(2 \times 150 \mathrm{~mL})$. The combined organic components were washed with sat. aq. $\mathrm{LiCl}(4 \times$ $100 \mathrm{~mL}$ ), filtered over an hydrophobic frit and concentrated in vacuo. Purification by silica gel chromatography (CombiflashRft, 80 g column), eluting with $\mathrm{CH}_{2} \mathrm{Cl}_{2}: \mathrm{MeOH}$ (1:0 to 10:1) afforded tert-butyl (7R)-4”'”-(4'-((8-cyclopentyl-7-ethyl-5-methyl-6-oxo5,6,7,8-tetrahydropteridin-2-yl)amino)-3'- methoxybenzamido)piperidine-1"'”-carboxylate (60) (736 mg, $64 \%)$ as a pale brown oil. A small amount of $60(50 \mathrm{mg})$ was further purified by MDAP (method D), while the rest was used as such in the following reactions. The mass-directed assisted purification (MDAP) preparative HPLC fractions were collected and concentrated in vacuo to give tert-butyl (7R)-4-(4-((8-cyclopentyl7-ethyl-5-methyl-6-oxo-5,6,7,8-tetrahydropteridin-2-yl)amino)-3methoxybenzamido)piperidine-1-carboxylate $(26 \mathrm{mg}, 51 \%$ recovery) as a colourless solid: $R_{f} 0.55\left(\mathrm{CH}_{2} \mathrm{Cl}_{2}: \mathrm{MeOH}: \mathrm{NH}_{4} \mathrm{OH}=\right.$ 90:9:1); $[\alpha]_{\mathrm{D}}^{25}:-44.9$ (c 1.0, MeOH) $\left[\right.$ lit. $^{41}[\alpha]_{D}^{22}:-112$ (c0.2, $\left.\left.\mathrm{CHCl}_{3}\right)\right]$; m.p. 88-90 ${ }^{\circ} \mathrm{C}\left(\mathrm{CH}_{2} \mathrm{Cl}_{2}\right)\left[\right.$ lit. ${ }^{41} 132{ }^{\circ} \mathrm{C}$ (EtOAc) ]; ${ }^{1} \mathrm{H}$ $\operatorname{NMR}\left(400 \mathrm{MHz}, \mathrm{CDCl}_{3}\right) \delta 8.51(1 \mathrm{H}, \mathrm{d}, J 8.4), 7.66(1 \mathrm{H}, \mathrm{s}), 7.41$ (1 H, d, J1.9), 7.23 (1 H, dd, J8.5, 1.9), 6.00 (1 H, d, J7.8), 4.56$4.40(1 \mathrm{H}, \mathrm{m}), 4.21(1 \mathrm{H}, \mathrm{dd}, J 7.9,3.7), 4.16-4.02(1 \mathrm{H}, \mathrm{m}), 3.96(3$ $\mathrm{H}, \mathrm{s}), 3.31$ (3 H, s), 2.92 (2 H, t, J12.6), 2.21-2.07 (3 H, m), 2.08$1.92(3 \mathrm{H}, \mathrm{m}), 1.92-1.60(8 \mathrm{H}, \mathrm{m}), 1.46(11 \mathrm{H}, \mathrm{s}), 0.87$ (3 H, dd, $J$ 7.5, 7.5); LCMS (high pH) rt 1.32 mins (97\%), $\mathrm{m} / z\left(\mathrm{ES}^{+}\right) 609$ $\left([\mathrm{M}+\mathrm{H}]^{+}, 100 \%\right)$; Chiral HPLC (IB-N5 $(250 \times 4.6 \mathrm{~mm}, 5 \mu \mathrm{m})$, Hexane:EtOH $=75: 25$ with $0.2 \% \mathrm{v} / \mathrm{v}$ isopropylamine, $1.0 \mathrm{~mL} / \mathrm{min}$, 25 mins) major rt 14.9 mins, $92.9 \%$, minor rt 17.9 mins, $7.1 \%$. The data are in good agreement with the literature. ${ }^{41}$

( 7R)-4-((8-Cyclopentyl-7-ethyl-5-methyl-6-oxo-5,6,7,8tetrahydropteridin-2-yl)amino)-3'-methoxy- $N$-(piperidin-4yl)benzamide (65)

Trifluoroacetic acid ( $1.52 \mathrm{ml}, 19.7 \mathrm{mmol}, 20.0$ eq.) was added to a solution of 8 ( $600 \mathrm{mg}, 0.987 \mathrm{mmol}, 1.00$ eq.) in $\mathrm{CH}_{2} \mathrm{Cl}_{2}(6.0 \mathrm{~mL})$ at $0{ }^{\circ} \mathrm{C}$. The reaction mixture was stirred for $1 \mathrm{~h}$ at $0{ }^{\circ} \mathrm{C}$, then the reaction mixture was warmed to room temperature, and stirred for 1 $\mathrm{h}$. The reaction mixture was concentrated in vacuo, then the residue was dissolved in $\mathrm{MeOH}(10 \mathrm{~mL})$ and $\mathrm{K}_{2} \mathrm{CO}_{3}(c a .2 \mathrm{~g})$ was added at $0{ }^{\circ} \mathrm{C}$. The mixture was stirred vigorously for $10 \mathrm{mins}$, then diluted with $\mathrm{H}_{2} \mathrm{O}(50 \mathrm{~mL})$ and extracted with EtOAc $(2 \times 50 \mathrm{~mL})$. The combined organic components were washed with $\mathrm{H}_{2} \mathrm{O}(25 \mathrm{~mL})$, then filtered over an hydrophobic frit and concentrated in vacuo. The residue was taken in minimal amount of $\mathrm{MeOH}$, then loaded onto a $10 \mathrm{~g} \mathrm{SCX}$ column, washed with $\mathrm{MeOH}(5 \times 20 \mathrm{~mL})$, then eluted with $2 \mathrm{M} \mathrm{NH}_{3}$ in $\mathrm{MeOH}(5 \times 10 \mathrm{~mL})$ using a fish tank. The collected fractions were concentrated in vacuo, then purified by silica gel chromatography (CombiflashRf, $40 \mathrm{~g}$ column), eluting with $\mathrm{CH}_{2} \mathrm{Cl}_{2}: 2 \mathrm{M} \mathrm{NH}_{3}$ in $\mathrm{MeOH}(1: 0$ to 8:2) to afford ( $7 R)-4-((8-$ cyclopentyl-7-ethyl-5-methyl-6-oxo-5,6,7,8-tetrahydropteridin-2-

yl)amino)-3-methoxy- $N$-(piperidin-4-yl)benzamide (65) (354 mg, $70 \%)$ as a beige solid $R_{f} 0.17\left(\mathrm{CH}_{2} \mathrm{Cl}_{2}: \mathrm{MeOH}: \mathrm{NH}_{4} \mathrm{OH}=90: 9: 1\right)$; $[\alpha]_{\mathrm{D}}^{25}:-92.1(c 1.0, \mathrm{MeOH})\left[\right.$ lit. $\left.^{41}[\alpha]_{D}^{22}:-86\left(c 0.2, \mathrm{CHCl}_{3}\right)\right]$; m.p. $164-166^{\circ} \mathrm{C}(\mathrm{MeOH}) ;\left[\mathrm{lit}^{41} 138^{\circ} \mathrm{C}(\text { EtOAc })\right]^{1} \mathrm{H} \mathrm{NMR}(400 \mathrm{MHz}$, $\left.\mathrm{CDCl}_{3}\right) \delta 8.54(1 \mathrm{H}, \mathrm{d}, J 8.4), 7.68(1 \mathrm{H}, \mathrm{s}), 7.59(1 \mathrm{H}, \mathrm{s}), 7.42(1 \mathrm{H}$, d, J2.0), 7.23 (1 H, dd, J8.4, 2.0), 5.95 (1 H, d, J8.0), $4.52(1 \mathrm{H}, \mathrm{p}$, J 8.0), 4.21 (1 H, dd, J7.9, 3.8), 4.16-4.04 (1 H, m), 3.97 (3 H, s), $3.33(3 \mathrm{H}, \mathrm{s}), 3.11(2 \mathrm{H}, \mathrm{dt}, J 12.8,3.8), 2.77(2 \mathrm{H}, \mathrm{td}, J 12.8,2.5)$, 2.23-1.92 (3 H, m), 1.92-1.58 (8 H, m), 1.52-1.35 (2 H, m), 0.88 (3 H, dd, J7.5, 7.5); LCMS (high pH) rt 1.15 mins (> 99\%), m/z $\left(\mathrm{ES}^{+}\right) 508\left([\mathrm{M}+\mathrm{H}]^{+}, 100 \%\right)$; HR-LCMS (formic acid) rt $1.92 \mathrm{mins}$ (95\%), $m / z\left(\mathrm{ES}^{+}\right)$found 508.3037 (100\%), $\mathrm{C}_{27} \mathrm{H}_{37} \mathrm{~N}_{7} \mathrm{O}_{3}$ requires $[\mathrm{M}+\mathrm{H}]^{+}$508.3031. Chiral HPLC (IE5 $(250 \times 4.6 \mathrm{~mm}, 5 \mu \mathrm{m})$, Hexane:IPA $=50: 50$ with $0.2 \% \mathrm{v} / \mathrm{v}$ isopropylamine, $1.0 \mathrm{~mL} / \mathrm{min}$, 30 mins) minor rt 19.0 mins, $9.0 \%$, major rt 21.4 mins, $90.0 \%$. The data are in good agreement with the literature. ${ }^{41}$ 


\section{3-(3H-Diazirin-3-yl)pentanoic acid (67)}

Levulinic acid (4.0 g, $34 \mathrm{mmol}, 1.0$ eq.) and $7 \mathrm{M} \mathrm{NH}_{3}$ in $\mathrm{MeOH}(45$ $\mathrm{mL}, 3.2 \mathrm{mmol}$, 9.1 eq.) were stirred at $0{ }^{\circ} \mathrm{C}$ for $3 \mathrm{~h}$, then hydroxylamine- $O$-sulfonic acid $(5.8 \mathrm{~g}, 51 \mathrm{mmol}, 1.5 \mathrm{eq}$. $)$ was added portionwise and the mixture was left to warm to room temperature then stirred for $42 \mathrm{~h}$. Nitrogen was bubbled through the reaction mixture for $1 \mathrm{~h}$ and the mixture was filtered. The retentate was washed with $\mathrm{MeOH}(2 \times 20 \mathrm{~mL})$ and the filtrate was concentrated in vacuo. The residue was dissolved in $\mathrm{MeOH}(25 \mathrm{~mL})$, triethylamine ( $14 \mathrm{~mL}, 10 \mathrm{mmol}, 3.0$ eq.) was added and the reaction mixture was cooled to $0{ }^{\circ} \mathrm{C}$. Iodine $(8.7 \mathrm{~g}, 34 \mathrm{mmol}, 1.0 \mathrm{eq}$.) was added portionwise at $0{ }^{\circ} \mathrm{C}$ under nitrogen in the dark with vigorous stirring until the dark colour remained. $2 \mathrm{M}$ aq. $\mathrm{HCl}(c a .30 \mathrm{~mL})$ and aq. sodium thiosulfate $(10 \% \mathrm{w} / \mathrm{v}, 150 \mathrm{~mL})$ were added, and the mixture was extracted with EtOAc $(3 \times 60 \mathrm{~mL})$. The combined organic components were washed with aq. sodium thiosulfate $(10 \%$ $w / v, 2 \times 100 \mathrm{~mL}$ ), then filtered over an hydrophobic frit and concentrated in vacuo. The crude was filtered over silica, flushing with $\mathrm{CH}_{2} \mathrm{Cl}_{2}: \mathrm{MeOH}(9: 1$, ca. $4 \mathrm{CV})$, then purified by silica gel chromatography (CombiflashRf $+80 \mathrm{~g}$ column), eluting with $\mathrm{CH}_{2} \mathrm{Cl}_{2}: \mathrm{MeOH}$ (1:0 to 9:1) to afford 3-(3-methyl-3H-diazirin-3yl)propanoic acid (67) $(1.02 \mathrm{~g}, 22 \%)$ as a colourless liquid. $R_{f} 0.05$ $\left(\mathrm{CH}_{2} \mathrm{Cl}_{2}: \mathrm{MeOH}=9: 1\right) ; \tilde{\mathrm{V}}_{\max }$ (neat) $/ \mathrm{cm}^{-1} 2980(\mathrm{w}), 2666(\mathrm{w}), 1708$ (s) (C=O), $1437(\mathrm{~m}), 1387(\mathrm{~m}), 1223(\mathrm{~m}), 918(\mathrm{w}) ;{ }^{1} \mathrm{H}(600 \mathrm{MHz}$, $\left.\mathrm{CDCl}_{3}\right) 2.25(2 \mathrm{H}, \mathrm{t}, J 6.5), 1.73(2 \mathrm{H}, \mathrm{t}, J 6.5), 1.06(3 \mathrm{H}, \mathrm{s}) ;{ }^{13} \mathrm{C}$ $\left(176 \mathrm{MHz} \mathrm{CDCl}_{3}\right) \delta 178.0,29.4,28.4,25.0$ 19.7; LCMS (formic acid) $\mathrm{rt} 0.36 \mathrm{mins}(20 \%), \mathrm{m} / z\left(\mathrm{ES}^{-}\right) 127\left([\mathrm{M}-\mathrm{H}]^{-}, 100 \%\right)$. The compound is not UV active, so LCMS or HPLC could not be used to determine purity. Purity by ${ }^{1} \mathrm{H}$ NMR is estimated at $>90 \%$. The data are in good agreement with the literature. ${ }^{42}$

(R)-4-((8-Cyclopentyl-7-ethyl-5-methyl-6-oxo-5,6,7,8tetrahydropteridin-2-yl)amino)-3-methoxy- $N$-(1-(3-(3-methyl$3 H$-diazirin-3-yl)propanoyl)piperidin-4-yl)benzamide (57)

HATU (17.8 mg, $0.047 \mathrm{mmol}, 1.2$ eq.) and DIPEA (14 $\mu \mathrm{L}$, $0.078 \mathrm{mmol}, 2.0$ eq. $)$ were added to a solution of 3-(3-methyl-3Hdiazirin-3-yl)propanoic acid (67) (5.0 mg, $0.039 \mathrm{mmol}, 1.0 \mathrm{eq}$.) in $\mathrm{CH}_{2} \mathrm{Cl}_{2}(0.4 \mathrm{~mL})$. The reaction was stirred for $1 \mathrm{~h}$ at room temperature, then (R)-4-((8-cyclopentyl-7-ethyl-5-methyl-6-oxo5,6,7,8-tetrahydropteridin-2-yl)amino)-3-methoxy-N-(piperidin-4yl)benzamide (65) (24 mg, $0.047 \mathrm{mmol}, 1.2 \mathrm{eq}$.) was added, and the mixture was stirred for $1.5 \mathrm{~h}$. The volatile components were removed under a flow of nitrogen, then the residue was dissolved in DMSO $(0.9 \mathrm{~mL})$ and purified by MDAP (method C). The solvents were removed under a flow of nitrogen to afford $(R)-4-((8-$ cyclopentyl7-ethyl-5-methyl-6-oxo-5,6,7,8-tetrahydropteridin-2-yl)amino)-3methoxy- $\mathrm{N}$-(1-(3-(3-methyl-3H-diazirin-3-

yl)propanoyl)piperidin-4-yl)benzamide (52) (14 mg, 53\%) as an amorphous colourless solid: $\mathrm{R}_{\mathrm{f}} 0.46$ (EtOAc); $[\alpha]_{\mathrm{D}}^{25}:-48.2$ (c 0.41, $\mathrm{MeOH}$ ); $\tilde{\mathrm{V}}_{\max }$ (thin film)/cm 3339 (w), 2967 (w), 1674 (br, s) $(\mathrm{C}=\mathrm{O}) 1630(\mathrm{~s})(\mathrm{C}=\mathrm{O}), 1502(\mathrm{~s}), 1381(\mathrm{~m}), 1322(\mathrm{~m}), 1245(\mathrm{~m})$, $1035(\mathrm{~m}), 953(\mathrm{w}), 757(\mathrm{w}) ;{ }^{1} \mathrm{H}$ NMR (700 MHz, $\left.\mathrm{CDCl}_{3}\right) 8.54$ (1 $\mathrm{H}, \mathrm{d}, J 8.4), 7.68(1 \mathrm{H}, \mathrm{s}), 7.65(1 \mathrm{H}, \mathrm{s}), 7.42(1 \mathrm{H}, \mathrm{d}, J 2.0), 7.23$ (1 $\mathrm{H}, \mathrm{dd}, J 8.5,2.0), 5.95(1 \mathrm{H}, \mathrm{d}, J 7.7), 4.60(1 \mathrm{H}, \mathrm{m}), 4.51(1 \mathrm{H}, \mathrm{tt}, J$ 8.0, 8.0), 4.25-4.16 (2 H, m), $3.98(3 \mathrm{H}, \mathrm{s}), 3.80(1 \mathrm{H}, \mathrm{m}), 3.33(3$ $\mathrm{H}, \mathrm{s}), 3.22-3.14(1 \mathrm{H}, \mathrm{m}), 2.81-2.72(1 \mathrm{H}, \mathrm{m}), 2.23-1.92(6 \mathrm{H}, \mathrm{m})$, 1.91-1.75 (6 H, m), 1.75-1.65 (4 H, m), 1.51-1.37 (2 H, m), 1.06 $(3 \mathrm{H}, \mathrm{s}), 0.88(3 \mathrm{H}, \mathrm{dd}, J 7.5,7.5) ;{ }^{13} \mathrm{C} \mathrm{NMR}\left(176 \mathrm{MHz}, \mathrm{CDCl}_{3}\right) \delta$ $169.6,166.7,163.7,155.0,152.3,147.3,137.7,133.4,126.1,118.9$,
116.5, 116.0,109.1, 59.9, 58.4, 56.0, 47.1, 44.4, 41.0, 32.9, 31.9, 29.7, 29.6, 29.3, 27.1, 25.5, 23.6, 23.2, 20.1, 9.2; LCMS (formic acid) rt $0.82 \mathrm{mins}(95 \%), \mathrm{m} / z\left(\mathrm{ES}^{+}\right) 618\left([\mathrm{M}+\mathrm{H}]^{+}, 100 \%\right) ; \mathrm{HRMS} \mathrm{m} / z$ $\left(\mathrm{ES}^{+}\right)$found $618.3486(100 \%), \mathrm{C}_{32} \mathrm{H}_{43} \mathrm{~N}_{9} \mathrm{O}_{4}[\mathrm{M}+\mathrm{H}]^{+}$requires 618.3511.

$(R)-3$ ',6'-diamino-[5/6]-(4-(4-((8-cyclopentyl-7-ethyl-5-methyl-6oxo-5,6,7,8-tetrahydropteridin-2-yl)amino)-3-

methoxybenzamido)piperidine-1-carbonyl)-3-oxo-3 $H$ -

spiro[isobenzofuran-1,9'-xanthene]-4',5'-disulfonate, dilithium salt (58)

(R)-4-((8-Cyclopentyl-7-ethyl-5-methyl-6-oxo-5,6,7,8-

tetrahydropteridin-2-yl)amino)-3-methoxy- $N$-(piperidin-4-

yl)benzamide ( $2.9 \mathrm{mg}, 5.8 \mu \mathrm{mol}, 1.5$ eq.) in DMSO $(0.4 \mathrm{~mL})$ was combined with AlexaFluor $^{\text {rm }} 488$ NHS Ester (3',6'-diamino-[5/6](((2,5-dioxopyrrolidin-1-yl)oxy) carbonyl)-3-oxo-3H-

spiro[isobenzofuran-1,9'-xanthene]-4',5'-disulfonate) $(65)(2.5 \mathrm{mg}$, $3.9 \mu \mathrm{mol}, 1.0$ eq.) in DMSO $(0.1 \mathrm{~mL})$. DIPEA ( $4.1 \mu \mathrm{L}, 23 \mu \mathrm{mol}$, 6.0 eq.) was added and the mixture was stirred in the dark for $18 \mathrm{~h}$. PyBOP ( $2.0 \mathrm{mg}, 3.9 \mu \mathrm{mol}, 1.0$ eq.) was added and the reaction mixture was stirred at room temperature for $30 \mathrm{mins}$ in the dark. The crude material was diluted with of DMSO $(1 \mathrm{~mL})$ and purified by MDAP (method B). Collected fractions were frozen in tared vials and lyophilised. The fractions were combined to afford $(R)-3^{\prime}, 6^{\prime}-$ diamino-6-(4-(4-((8-cyclopentyl-7-ethyl-5-methyl-6-oxo-5,6,7,8tetrahydropteridin-2-yl)amino)-3-methoxybenzamido)piperidine1-carbonyl)-3-oxo-3 $H$-spiro[isobenzofuran-1,9'-xanthene]-4',5'disulfonate, dilithium salt (58) $(1.5 \mathrm{mg}, 34 \%)$ as an amorphous bright yellow solid: LCMS (high $\mathrm{pH}$ ) rt: $0.74 \mathrm{mins}(100 \%), \mathrm{m} / \mathrm{z}$ $\left.\left.\left(\mathrm{ES}^{+}\right) 513.3[\mathrm{M}+2 \mathrm{H}]^{2+}, 45 \%\right), 521.8[\mathrm{M}+\mathrm{H}+\mathrm{Na}]^{2+}, 100 \%\right)$; HRLCMS (formic acid) rt: $3.54 \mathrm{mins}(70 \%), \mathrm{m} / z\left(\mathrm{ES}^{+}\right)$1024.2938, $\mathrm{C}_{48} \mathrm{H}_{49} \mathrm{~N}_{9} \mathrm{O}_{13} \mathrm{~S}_{3}$ requires $[\mathrm{M}+\mathrm{H}]^{+} 1024.2970$; Two peaks seen in the LCMS due to partial separation of the 5- and 6-regioisomers in the 10 mins LC method. LCMS consistent with product with purity > $90 \%$.

2-Amino-8-cyclopentyl-7-ethyl-5-methyl-7,8-dihydropteridin6(5H)-one $(66)$

(R)-2-Chloro-8-cyclopentyl-7-ethyl-5-methyl-7,8-dihydropteridin$6(5 H)$-one $(8)(0.15 \mathrm{~g}, 0.51 \mathrm{mmol}, 1.0$ eq. $)$ was dissolved in isopropanol $(1.2 \mathrm{~mL})$ and ammonium hydroxide $(2.6 \mathrm{~mL}, 70 \mathrm{mmol}$, 250 eq.), then submitted to microwave irradiation for $6 \mathrm{~h}$ at $170^{\circ} \mathrm{C}$, $6 \mathrm{~h}$ at $160^{\circ} \mathrm{C}$ and then $4 \mathrm{~h}$ at $170{ }^{\circ} \mathrm{C} . \mathrm{H}_{2} \mathrm{O}(150 \mathrm{~mL})$ was added and the mixture was extracted with EtOAc $(150 \mathrm{~mL})$. The organic components were filtered over an hydrophobic frit. Purification by silica gel chromatography (Combiflash $R f+, 24 \mathrm{~g}$ column), eluting with cyclohexane:EtOAc $(1: 0$ to $0: 1)$ and then with $\mathrm{EtOH}: \mathrm{Et}_{3} \mathrm{~N}$ (9:1, 2 CV), afforded 2-amino-8-cyclopentyl-7-ethyl-5-methyl-7,8dihydropteridin-6(5H)-one (66) (112 mg, 80\%) as a colourless oil: $R_{f} 0.30$ (EtOAc); $\tilde{\mathrm{V}}_{\max }$ (thin film)/ $\mathrm{cm}^{-1} 3339$ (w), 2970 (w), 2873 (w), $1665(\mathrm{~s})(\mathrm{C}=\mathrm{O}), 1459(\mathrm{~s}), 1247(\mathrm{~m}), 954(\mathrm{~m}) ;{ }^{1} \mathrm{H} \operatorname{NMR}(600$ MHz, DMSO-D 6$) \delta 7.58(1 \mathrm{H}, \mathrm{s}), 5.87(2 \mathrm{H}, \mathrm{s}), 4.36-4.27(1 \mathrm{H}, \mathrm{m})$, 4.07 ( $1 \mathrm{H}, \mathrm{dd}, J 7.9,3.7)$, 3.17 (3 H, s), 1.93-1.83 (2 H, m), 1.791.65 ( $5 \mathrm{H}, \mathrm{m}), 1.62-1.48$ (3 H, m), $0.75(3 \mathrm{H}, \mathrm{dd}, J 7.5,7.5) ;{ }^{13} \mathrm{C}$ NMR (151 MHz, DMSO-D 6$) \delta 162.7,159.1,151.7,139.2,113.8$, 59.6, 57.5, 28.9, 28.7, 27.6, 26.1, 23.4, 23.1, 9.0. LCMS (formic acid) rt 0.52 mins (96\%), $\mathrm{m} / z\left(\mathrm{ES}^{+}\right) 277\left([\mathrm{M}+\mathrm{H}]^{+}, 100 \%\right)$. 
$N$-(8-Cyclopentyl-7-ethyl-5-methyl-6-oxo-5,6,7,8-

tetrahydropteridin-2-yl)-3-(3-methyl-3 $H$-diazirin-3-

yl)propenamide (56)

HATU (72 mg, 0.19 mmol, 1.2 eq.) and DIPEA (0.055 mL, 0.31 mmol, 2.0 eq.) were added to a solution of 3-(3-methyl-3 $H$-diazirin3-yl)propanoic acid (67) (20 mg, $0.16 \mathrm{mmol}, 1.0$ eq.) in $\mathrm{CH}_{2} \mathrm{Cl}_{2}$ $(1.0 \mathrm{~mL})$. The reaction mixture was stirred for $1.5 \mathrm{~h}$ at room temperature, then 2-amino-8-cyclopentyl-7-ethyl-5-methyl-7,8dihydropteridin- $6(5 \mathrm{H})$-one $(66)(52 \mathrm{mg}, 0.19 \mathrm{mmol}, 1.2$ eq. $)$ in $\mathrm{CH}_{2} \mathrm{Cl}_{2}(0.5 \mathrm{~mL})$.was added. The reaction mixture was stirred for $2.5 \mathrm{~h}$, then HATU (72 mg, $0.19 \mathrm{mmol}, 1.2 \mathrm{eq}$.) and DIPEA (0.055 $\mathrm{mL}, 0.31 \mathrm{mmol}, 2.0$ eq.) were added. The reaction was stirred for $2 \mathrm{~h}$, then left to stand for $48 \mathrm{~h}$. Evaporation was observed, hence $\mathrm{CH}_{2} \mathrm{Cl}_{2}(0.5 \mathrm{ml})$ and DMF $(0.25 \mathrm{~mL})$ were added to re-solubilise the mixture. HATU ( $72 \mathrm{mg}, 0.19 \mathrm{mmol}, 1.2 \mathrm{eq}$.) and DIPEA ( 0.055 $\mathrm{mL}, 0.31 \mathrm{mmol}, 2.0$ eq.) were added and the RM was stirred at room temperature for $18 \mathrm{~h}$. The reaction mixture was diluted with $\mathrm{H}_{2} \mathrm{O}$ $(30 \mathrm{~mL})$, then extracted with EtOAc $(2 \times 30 \mathrm{~mL})$. The combined organic components were washed with sat. aq. $\mathrm{LiCl}(50 \mathrm{~mL})$, then concentrated in vacuo. The residue was dissolved in $\mathrm{MeOH}$ :DMSO $(1: 1,1 \mathrm{~mL})$ and purified by MDAP (method C). The fractions were combined and concentrated under a flow of nitrogen in the dark to afford $\quad N$-(8-cyclopentyl-7-ethyl-5-methyl-6-oxo-5,6,7,8tetrahydropteridin-2-yl)-3-(3-methyl-3 $H$-diazirin-3-

yl)propenamide (56) (36 mg, 57\%) as an off-white powdery solid: $R_{f} 0.20$ (petroleum ether:EtOAc $\left.=1: 1\right) ; \tilde{\mathrm{V}}_{\max }\left(\right.$ thin film) $/ \mathrm{cm}^{-1} 3339$ (w), 2970 (w), 2873 (w), 1665 (s) (C=O), 1459 (s), 1247 (m), $954(\mathrm{~m}) ;{ }^{1} \mathrm{H}$ NMR (600 MHz, DMSO-D $) \delta 7.58(1 \mathrm{H}, \mathrm{s}), 5.87$ (2 H, s), 4.36-4.27 (1 H, m), 4.07 (1 H, dd, J 7.9, 3.7), 3.17 (3 $\mathrm{H}, \mathrm{s}), 1.93-1.83(2 \mathrm{H}, \mathrm{m}), 1.79-1.65(5 \mathrm{H}, \mathrm{m}), 1.62-1.48(3 \mathrm{H}$, $\mathrm{m}), 0.75$ (3 H, dd, $J 7.5,7.5) ;{ }^{13} \mathrm{C}$ NMR (151 MHz, DMSO-D $)$ $\delta 162.7,159.1,151.7,139.2,113.8,59.6,57.5,28.9,28.7,27.6$, 26.1, 23.4, 23.1, 9.0. LCMS (high pH) rt 1.08 mins (100\%), $\mathrm{m} / z$ $\left(\mathrm{ES}^{+}\right) 387\left([\mathrm{M}+\mathrm{H}]^{+}, 100 \%\right)$; HR-LCMS (formic acid) rt 2.91 mins $(100 \%), m / z\left(\mathrm{ES}^{+}\right)$found 386.2311 (100\%), $\mathrm{C}_{19} \mathrm{H}_{27} \mathrm{~N}_{7} \mathrm{O}_{2}$ requires $[\mathrm{M}+\mathrm{H}]^{+} 386.2299$.

(7R)-8-Cyclopentyl-2-((2',4'-difluorophenyl)amino)-7-ethyl-5methyl-7,8-dihydropteridin-6(5H)-one $(55)$

(R)-2-Chloro-8-cyclopentyl-7-ethyl-5-methyl-7,8-dihydropteridin$6(5 H)$-one (8) (20 mg, $0.068 \mathrm{mmol}, 1.0$ eq.) was suspended in $\mathrm{H}_{2} \mathrm{O}$ $(0.8 \mathrm{~mL})$ and EtOH $(0.2 \mathrm{~mL}) .2$-4-difluoronaniline $(12 \mu \mathrm{L}$, $0.14 \mathrm{mmol}, 2.0 \mathrm{eq}$.) and $20 \mu \mathrm{L}$ conc. $\mathrm{HCl}$ were added. The resulting solution was stirred under reflux conditions for $18 \mathrm{~h}$, then sat. aq. $\mathrm{NaHCO}_{3}(20 \mathrm{~mL})$ was added. The mixture was extracted with $\mathrm{CH}_{2} \mathrm{Cl}_{2}(2 \times 40 \mathrm{~mL})$. The combined organic components were washed with sat. aq. $\mathrm{NaHCO}_{3}(20 \mathrm{~mL})$, dried over $\mathrm{MgSO}_{4}$, filtered, and concentrated in vacuo. Purification by silica gel chromatography, eluting with petroleum ether and EtOAc (1:0 to 0:1), afforded (7R)-8-cyclopentyl-2-((2',4'difluorophenyl)amino)-7-ethyl-5-methyl-7,8-dihydropteridin-

$6(5 H)$-one $(54)$ as an amorphous brown solid $(26 \mathrm{mg},>99 \%): R_{f}$ 0.79 (petroleum ether:EtOAc $=1: 1) ;[\alpha]_{D}^{25}:-57.8\left(c 1.0, \mathrm{CHCl}_{3}\right)$; $\tilde{\mathrm{V}}_{\max }$ (thin film)/ $\mathrm{cm}^{-1} 3053(\mathrm{w}), 1673$ (s, C=O) , 1974 (w), 1506 (m), $1428(\mathrm{~s}), 1279(\mathrm{~m}), 845(\mathrm{~m}), 778(\mathrm{~m}) ;{ }^{1} \mathrm{H}$ NMR (500 MHz, $\left.\mathrm{CDCl}_{3}\right) \delta 8.37-8.24(1 \mathrm{H}, \mathrm{m}), 7.63(1 \mathrm{H}, \mathrm{s}), 6.93-6.82(2 \mathrm{H}, \mathrm{m})$, 6.82-6.71 (1 H, m), 4.47-4.32 (1 H, m), 4.20 (1 H, dd, J7.8, 3.7), $3.31(3 \mathrm{H}, \mathrm{s}), 2.13-2.02(1 \mathrm{H}, \mathrm{m}), 2.02-1.89(1 \mathrm{H}, \mathrm{m}), 1.90-1.74(4$ $\mathrm{H}, \mathrm{m}), 1.74-1.54(4 \mathrm{H}, \mathrm{m}), 0.87$ (3 H, dd, J7.5, 7.5); ${ }^{13} \mathrm{C}$ NMR (126
$\left.\mathrm{MHz}, \mathrm{CDCl}_{3}\right) \delta 163.7,157.0\left(\mathrm{dd}, J_{C F} 244.3,11.6\right), 152.4$ (dd, $J_{C F}$ 244.3, 11.6), 155.3, 152.3, 137.8, 125.1, 121.3 (dd, $J_{C F} 8.6,2.4$ ), $116.4,110.5$ (dd, $J_{C F} 21.4,3.6$ ), 103.4 (dd, $J_{C F} 26.6,26.6$ ), 60.2, 58.6, 29.6, 29.2, 28.2, 27.2, 23.5, 23.2, 9.2; ${ }^{19} \mathrm{~F} \mathrm{NMR}\left(471 \mathrm{MHz}, \mathrm{CDCl}_{3}\right) \delta$ - 126.8 ( $1 \mathrm{~F}$, br d, $J_{C F} 2.9$ ), - 119.0 ( $1 \mathrm{~F}$, br s); LRMS $m / z\left(\mathrm{ES}^{+}\right) 388$ $\left([\mathrm{M}+\mathrm{H}]^{+}, 100 \%\right)$; HRMS $\mathrm{m} / z\left(\mathrm{ES}^{+}\right)$found $388.19406(100 \%)$, $\mathrm{C}_{20} \mathrm{H}_{23} \mathrm{ON}_{5} \mathrm{~F}_{2}$ requires $[\mathrm{M}+\mathrm{H}]^{+} 388.19434$; Analytical HPLC (RP, method B) rt 7.53 mins, purity $99 \%$.

( $7 R)$-8-Cyclopentyl-7-ethyl-5-methyl-2-((4'-(2,2,2-

trifluoroacetyl)phenyl)amino)-7,8-dihydropteridin-6(5H)-one (55)

(Trifluoroacetyl)aniline ( $77 \mathrm{mg}, 0.41 \mathrm{mmol}, 2.0$ eq.) and conc. $\mathrm{HCl}$ $(60 \mu \mathrm{L})$ were added to a suspension of $(R)$-2-chloro-8-cyclopentyl7-ethyl-5-methyl-7,8-dihydropteridin-6 $(5 H)$-one $\quad(8) \quad(60 \mathrm{mg}$, $0.21 \mathrm{mmol}, 1.0$ eq. $)$ in $\mathrm{H}_{2} \mathrm{O}(2.4 \mathrm{~mL})$ and $\mathrm{EtOH}(0.6 \mathrm{~mL})$. The resulting solution was stirred under reflux for $50 \mathrm{~h}$. The precipitated mixture was suspended in $\mathrm{H}_{2} \mathrm{O}(10 \mathrm{~mL})$, the $\mathrm{pH}$ was adjusted to $\mathrm{pH}$ 5-6 using sat. $\mathrm{K}_{2} \mathrm{CO}_{3}$, then was fully solubilised using $0.5 \mathrm{M}$ citric acid $(30 \mathrm{~mL})$ and $\mathrm{H}_{2} \mathrm{O}(10 \mathrm{~mL})$. The mixture was extracted with $\mathrm{CH}_{2} \mathrm{Cl}_{2}(2 \times 125 \mathrm{~mL})$. The combined organic components were washed with $0.5 \mathrm{M}$ citric acid $(2 \times 50 \mathrm{~mL})$, dried over $\mathrm{MgSO}_{4}$, filtered, and concentrated in vacuo. Purification by silica gel chromatography, eluting with petroleum ether and EtOAc (slow gradient from $1: 0$ to $1: 1$, then fast gradient from $1: 1$ to $0: 1)$, afforded (7R)-8-cyclopentyl-7-ethyl-5-methyl-2-((4-(2,2,2-

trifluoroacetyl)phenyl)amino)-7,8-dihydropteridin-6(5H)-one

(55) (26 mg, 28\%) as bright yellow solid: $R_{f} 0.31$ (petroleum ether:EtOAc = 1:1); $[\alpha]_{D}^{25}:-66.0\left(\right.$ c 1.0, $\left.\mathrm{CHCl}_{3}\right)$; m.p. $183-185^{\circ} \mathrm{C}$ (EtOAc); $\tilde{\mathrm{V}}_{\max }$ (thin film) $/ \mathrm{cm}^{-1} 3267(\mathrm{w}), 2966(\mathrm{w}), 1656(\mathrm{~s})$ $(\mathrm{C}=\mathrm{O}), 1601$ (s) (C=O), $1584(\mathrm{~s}), 1424(\mathrm{~s}), 1340(\mathrm{~m}), 1238(\mathrm{~m})$, $1162(\mathrm{w}), 1141(\mathrm{~m}), 935(\mathrm{~m}), 765(\mathrm{~m}) ;{ }^{1} \mathrm{H}$ NMR $(400 \mathrm{MHz}$, $\left.\mathrm{CDCl}_{3}\right) \delta 8.08-7.97(2 \mathrm{H}, \mathrm{m}), 7.82-7.73(2 \mathrm{H}, \mathrm{m}), 7.69(1 \mathrm{H}, \mathrm{s})$, 7.30 ( $1 \mathrm{H}, \mathrm{br} \mathrm{s}), 4.55-4.39$ ( $1 \mathrm{H}, \mathrm{m}), 4.25$ ( $1 \mathrm{H}, \mathrm{dd}, J 7.8,3.7), 3.34$ (3 H, s), 2.23-2.08 (1 H, m), 2.08-1.95 (1 H, m), 1.95-1.52 (8 H, m), $0.88(3 \mathrm{H}, \mathrm{dd}, J 7.6,7.6) ;{ }^{13} \mathrm{C} \mathrm{NMR}\left(126 \mathrm{MHz} \mathrm{CDCl}_{3}\right) \delta 178.8$ (q) $J_{C F} 34.2$ ), 163.6, 154.3, 152.39, 147.2, 137.54, 132.2, 122.6, 117.26, 117.17 (q, $\left.J_{C F} 290.0, C F_{3}\right), 60.2,58.8,29.8,29.3,28.4,27.4$, 23.6, 23.3, 9.3; ${ }^{19} \mathrm{~F} \mathrm{NMR}\left(471 \mathrm{MHz}, \mathrm{CDCl}_{3}\right) \delta-70.8$ (3 F, br s, $\left.\mathrm{CF}_{3}\right)$; LRMS $m / z\left(\mathrm{ES}^{+}\right) 448\left([\mathrm{M}+\mathrm{H}]^{+}, 100 \%\right)$; HRMS $m / z\left(\mathrm{ES}^{+}\right)$found 448.19522 (100\%), $\mathrm{C}_{22} \mathrm{H}_{24} \mathrm{~F}_{3} \mathrm{~N}_{5} \mathrm{O}_{2}$ requires $[\mathrm{M}+\mathrm{H}]^{+}$448.19549; Analytical HPLC (RP, method B) rt 6.47 mins, purity $98 \%$.

\section{ASSOCIATED CONTENT}

\section{Supporting Information}

For general synthetic procedures, intermediate characterisation, assay and modelling procedures, please refer to the supporting information.

Supplementary information (biological data and synthesis) (pdf)

\section{AUTHOR INFORMATION}

\section{Corresponding Author}

stuart.conway@chem.ox.ac.uk 


\section{Funding Sources}

C.M.C.L. thanks the BBSRC for studentship support (BB/M015157/1). J.P.B. and L.E.J. were supported by the EPSRC and the MRC through the Systems Approaches to Biomedical Sciences Doctoral Training Centre (EP/G037280/1) with additional support from GlaxoSmithKline. D.S.H. thanks Cancer Research UK for a studentship. A.R.S. thank the EPSRC Centre for Doctoral Training in Synthesis for Biology and Medicine (EP/L015838/1) and AstraZeneca, Diamond Light Source, Defence Science and Technology Laboratory, Evotec, GlaxoSmithKline, Janssen, Novartis, Pfizer, Syngenta, Takeda, UCB, and Vertex for studentship support. M.S. was supported by the Deutsche Forschungsgemeinschaft (SCHI 1408/1-1). S.J.C. and A.K.N.C. thank the European Commission for the award of a Marie Curie Fellowship for A.K.N.C. (660156, FLUOROKEF). P.C.B. thanks Lady Margaret Hall, Oxford for research funding. S.J.C. thanks St Hugh's College, Oxford, for research funding.

\section{ACKNOWLEDGMENT}

We thank Emma Grant and Dr Jacob Bush for advice on cross-linking experiments. We are grateful to Prof. Timothy Claridge for advice on NMR titration. C.M.C.L also thanks Jon Seal for helpful synthetic insight. We would like to acknowledge the use of the University of Oxford Advanced Research Computing (ARC) facility in carrying out this work: http://dx.doi.org/10.5281/zenodo.22558.

\section{REFERENCES}

1. Research Priorities for Chagas Disease, Human African Trypanosomiasis and Leishmaniasis. World Health Organisation: WHO Technical Report Series, 2012.

2. Rassi Jr, A.; Rassi, A.; Marin-Neto, J. A., Chagas disease. The Lancet 2010, 375, 1388-1402.

3. Atwood, J. A.; Weatherly, D. B.; Minning, T. A.; Bundy, B.; Cavola, C.; Opperdoes, F. R.; Orlando, R.; Tarleton, R. L., The Trypanosoma cruzi Proteome. Science 2005, 309, 473-476.

4. Alonso, V. L.; Villanova, G. V.; Ritagliatib, C.; Mottac, M. C. M.; Cribba, P.; Serra, E. C., Trypanosoma cruzi Bromodomain Factor 3 Binds Acetylated $\alpha$-Tubulin and Concentrates in the Flagellum during Metacyclogenesis. Eukaryot. Cell 2014, 13, 822-831.

5. Arrowsmith, C. H.; Bountra, C.; Fish, P. V.; Lee, K.; Schapira, M., Epigenetic protein families: a new frontier for drug discovery. Nat. Rev. Drug Discov. 2012, 11, 384-400.

6. Filippakopoulos, P.; Knapp, S., The bromodomain interaction module. FEBS Lett. 2012, 586, 2692-2704.

7. Schiedel, M.; Moroglu, M.; Ascough, D. M. H.; Chamberlain, A. E. R.; Kamps, J. J. A. G.; Sekirnik, A. R.; Conway, S. J., Chemical epigenetics: the impact of chemical- and chemical biology techniques on bromodomain target validation. Angew. Chem. Int. Ed. 2019, 58, 17930-17952.

8. Hewings, D. S.; Rooney, T. P. C.; Jennings, L. E.; Hay, D. A.; Schofield, C. J.; Brennan, P. E.; Knapp, S.; Conway, S. J., Progress in the Development and Application of Small Molecule Inhibitors of Bromodomain-Acetyl-lysine Interactions. J. Med. Chem. 2012, 55, 9393-9413.

9. Brand, M.; Measures, A. M.; Wilson, B. G.; Cortopassi, W. A.; Alexander, R.; Höss, M.; Hewings, D. S.; Rooney, T. P. C.; Paton, R. S.; Conway, S. J., Small Molecule Inhibitors of Bromodomain-Acetyl-lysine Interactions. ACS Chem. Biol. 2015, 10, 22-39.

10. Cochran, A. G.; Conery, A. R.; Sims, R. J., Bromodomains: a new target class for drug development. Nat. Rev. Drug Discov. 2019, 18, 609-628.
11. Alonso, V. L.; Serra, E. C., Lysine Acetylation: Elucidating the Components of an Emerging Global Signaling Pathway in Trypanosomes. J. Biomed. and Biotech. 2012, 2012, 1-16.

12. Tallant, C.; Bambarough, P.; Gamo, F. J.; Martín, J.; Prinjha, R.; Rioja, I.; Simola, D. F.; Chung, C.-w.; Gabarró R.; Félix, C., Expanding Bromodomain Targeting into Neglected Infectious Diseases. ACS Infect. Dis. 2020, submitted.

13. Villanova, G. V.; Nardelli, S. C.; Cribb, P.; Magdaleno, A.; Silber, A. M.; Motta, M. C. M.; Schenkman, S.; Serra, E., Trypanosoma cruzi Bromodomain Factor 2 (BDF2) Binds to Acetylated Histones and is Accumulated After UV Irradiation. Int. J. Parasitol. 2009, 39, 665-673.

14. Ritagliati, C.; Villanova, G. V.; Alonso, V. L.; Zuma, A. A.; Cribb, P.; Motta, M. Cristina M.; Serra, E. C., Glycosomal Bromodomain Factor 1 from Trypanosoma cruzi Enhances Trypomastigote Cell Infection and Intracellular Amastigote Growth. Biochem. J. 2015, 473, 73-85.

15. Dey, A.; Nishiyama, A.; Karpova, T.; McNally, J.; Ozato, K., Brd4 Marks Select Genes on Mitotic Chromatin and Directs Postmitotic Transcription. Mol. Bio. Cell 2009, 20 4899-4909.

16. Chung, C.-w.; Tough, D. F., Bromodomains: a new target class for small molecule drug discovery. Drug Discov. Today Ther. Strateg. 2012, 9, 111-120.

17. Filippakopoulos, P.; Knapp, S., Targeting Bromodomains: Epigenetic Readers of Lysine Acetylation. Nat. Rev. Drug Discov. 2014, 13, 337-356.

18. Sali, A.; Blundell, T. L., Comparative protein modelling by satisfaction of spatial restraints. J. Mol. Biol. 1993, 234, 779-815.

19. Alonso, V. L.; Ritagliati, C.; Cribb, P.; Cricco, J. A.; Serra, E. C., Overexpression of Bromodomain Factor 3 in Trypanosoma cruzi (TcBDF3) Affects Differentiation of the Parasite and Protects it Against Bromodomain Inhibitors. FEBS 2016, 283, 2051-2066.

20. Schulz, D.; Mugnier, M. R.; Paulsen, E.-M.; Kim, H.-S.; Chung, C.-w. W.; Tough, D. F.; Rioja, I.; Prinjha, R. K.; Papavasiliou, F. N.; Debler, E. W., Bromodomain Proteins Contribute to Maintenance of Bloodstream Form Stage Identity in the African Trypanosome. PLoS Biol. 2015, 13, e1002316.

21. Dawson, M. A.; Prinjha, R. K.; Dittmann, A.; Giotopoulos, G.; Bantscheff, M.; Chan, W.-I.; Robson, S. C.; Chung, C.w.; Hopf, C.; Savitski, M. M.; Huthmacher, C.; Gudgin, E.; Lugo, D.; Beinke, S.; Chapman, T. D.; Roberts, E. J.; Soden, P. E.; Auger, K. R.; Mirguet, O.; Doehner, K.; Delwel, R.; Burnett, A. K.; Jeffrey, P.; Drewes, G.; Lee, K.; Huntly, B. J. P.; Kouzarides, T., Inhibition of BET recruitment to chromatin as an effective treatment for MLLfusion leukaemia. Nature 2011, 478, 529-533.

22. Hewings, D. S.; Wang, M.; Philpott, M.; Fedorov, O.; Uttarkar, S.; Filippakopoulos, P.; Picaud, S.; Vuppusetty, C.; Marsden, B.; Knapp, S.; Conway, S. J.; Heightman, T. D., 3,5-Dimethylisoxazoles Act As Acetyl-lysine-mimetic Bromodomain Ligands. J. Med. Chem. 2011, 54, 67616770.

23. Hewings, D. S.; Fedorov, O.; Filippakopoulos, P.; Martin S.; Picaud, S.; Tumber, A.; Wells, C.; Olcina, M. M.; Freeman, K.; Gill, A.; Ritchie, A. J.; Sheppard, D. W.; Russell, A. J.; Hammond, E. M.; Knapp, S.; Brennan, P. E.; Conway, S. J., Optimization of 3,5-Dimethylisoxazole Derivatives as Potent Bromodomain Ligands. J. Med. Chem. 2013, 56, 3217-3227.

24. Hay, D. A.; Fedorov, O.; Martin, S.; Singleton, D. C.; Tallant, C.; Wells, C.; Picaud, S.; Philpott, M.; Monteiro, O. P.; Rogers, C. M.; Conway, S. J.; Rooney, T. P. C.; Tumber, A.; Yapp, C.; Filippakopoulos, P.; Bunnage, M. E.; Müller, S.; Knapp, S.; Schofield, C. J.; Brennan, P. E., Discovery and Optimization of Small-Molecule Ligands for the CBP/p300 Bromodomains. J. Am. Chem. Soc. 2014, 136, 9308-9319. 
Humphreys, P. G.; Bamborough, P.; Chung, C.-w.; Craggs, P. D.; Gordon, L.; Grandi, P.; Hayhow, T. G.; Hussain, J.; Jones, K. L.; Lindon, M.; Michon, A.-M.; Renaux, J. F.; Suckling, C. J.; Tough, D. F.; Prinjha, R. K., Discovery of a Potent, Cell Penetrant, and Selective p300/CBP-Associated Factor (PCAF)/General Control Nonderepressible 5 (GCN5) Bromodomain Chemical Probe. J. Med. Chem. 2017, 60, 695-709.

26. Gosmini, R.; Nguyen, V. L.; Toum, J.; Simon, C.; Brusq J.-M. G.; Krysa, G.; Mirguet, O.; Riou-Eymard, A. M.; Boursier, E. V.; Trottet, L.; Bamborough, P.; Clark, H.; Chung, C.-w.; Cutler, L.; Demont, E. H.; Kaur, R.; Lewis, A. J.; Schilling, M. B.; Soden, P. E.; Taylor, S.; Walker, A. L.; Walker, M. D.; Prinjha, R. K.; Nicodème, E., The Discovery of I-BET726 (GSK1324726A), a Potent Tetrahydroquinoline ApoA1 Up-Regulator and Selective BET Bromodomain Inhibitor. J. Med. Chem. 2014, 57, 8111-8131.

27. Popp, T. A.; Tallant, C.; Rogers, C.; Fedorov, O.; Brennan, P. E.; Müller, S.; Knapp, S.; Bracher, F., Development of Selective CBP/P300 Benzoxazepine Bromodomain Inhibitors. J. Med. Chem. 2016, 59, 8889-8912.

28. Ramallo, I. A.; Alonso, V. L.; Rua, F.; Serra, E.; Furlan, R. L. E., A Bioactive Trypanosoma cruzi Bromodomain Inhibitor from Chemically Engineered Extracts. ACS Comb. Sci. 2018, 20, 220-228.

29. García, P.; Alonso, V. L.; Serra, E.; Escalante, A. M.; Furlan, R. L. E., Discovery of a Biologically Active Bromodomain Inhibitor by Target-Directed Dynamic Combinatorial Chemistry. ACS Med. Chem. Lett. 2018, 9 1002-1006.

30. Dalvit, C.; Fogliatto, G.; Stewart, A.; Veronesi, M.; Stockman, B., WaterLOGSY as a Method for Primary NMR Screening: Practical Aspects and Range of Applicability. J. Biomol. NMR 2001, 21, 349-359.

31. Fielding, L., NMR Methods for the Determination of Protein- Ligand Dissociation Constants. Curr. Top. Med. Chem. 2003, 3, 39-53.

32. Bradner, J., E.; Gray, N.; QI, J.; McKenown, M., R.; Buckley, D. Dihydropteridinone Derivatives and Uses there of. WO/2015/117055, 2015.

33. Brand, M.; Clayton, J.; Moroglu, M.; Schiedel, M.; Picaud S.; Bluck, J.; Skwarska, A.; Chan, A.; Laurin, C.; Scorah, A.; See, L.; Rooney, T.; Fedorov, O.; Perell, G.; Kalra, P.; Cortopassi, W.; Christensen, K.; Cooper, R.; Paton, R.; Pomerantz, W.; Biggin, P.; Hammond, E. M.; Filippakopoulos, P.; Conway, S. J., Controlling Intramolecular Interactions in the Design of Selective, High-Affinity, Ligands for the CREBBP Bromodomain. ChemRxiv. Preprint. 2020, https://doi.org/10.26434/chemrxiv.12081999.v12081991.
34. Preston, G. W.; Wilson, A. J., Photo-induced covalent cross-linking for the analysis of biomolecular interactions. Chem. Soc. Rev. 2013, 42, 3289-3301.

35. Ciceri, P.; Müller, S.; O'Mahony, A.; Fedorov, O.; Filippakopoulos, P.; Hunt, J. P.; Lasater, E. A.; Pallares, G.; Picaud, S.; Wells, C.; Martin, S.; Wodicka, L. M.; Shah, N. P.; Treiber, D. K.; Knapp, S., Dual KinaseBromodomain Inhibitors for Rationally Designed Polypharmacology. Nat. Chem. Bio. 2014, 10, 305-312.

36. Steegmaier, M.; Hoffmann, M.; Baum, A.; Lénárt, P.; Petronczki, M.; Krššák, M.; Gürtler, U.; Garin-Chesa, P.; Lieb, S.; Quant, J.; Grauert, M.; Adolf, G. R.; Kraut, N.; Peters, J.-M.; Rettig, W. J., BI-2536, a Potent and Selective Inhibitor of Polo-like Kinase 1, Inhibits Tumor Growth In Vivo. Curr. Bio. 2007, 17, 316-322.

37. Seal, J.; Lamotte, Y.; Donche, F.; Bouillot, A.; Mirguet, O.; Gellibert, F.; Nicodeme, E.; Krysa, G.; Kirilovsky, J.; Beinke, S.; McCleary, S.; Rioja, I.; Bamborough, P.; Chung, C.-W.; Gordon, L.; Lewis, T.; Walker, A. L.; Cutler, L.; Lugo, D.; Wilson, D. M.; Witherington, J.; Lee, K.; Prinjha, R. K., Identification of a novel series of BET family bromodomain inhibitors: Binding mode and profile of $\mathrm{I}$ BET151 (GSK1210151A). Bioorg. Med. Chem. Lett. 2012, 22, 2968-2972.

38. Rudolph, D.; Steegmaier, M.; Hoffmann, M.; Grauert, M.; Baum, A.; Quant, J.; Haslinger, C.; Garin-Chesa, P.; Adolf, G. R., BI 6727, A Polo-like Kinase Inhibitor with Improved Pharmacokinetic Profile and Broad Antitumor Activity. Clin. Cancer Res. 2009, 15, 3094-3102.

39. Watts, E.; Heidenreich, D.; Tucker, E.; Raab, M.; Strebhardt, K.; Chesler, L.; Knapp, S.; Bellenie, B.; Hoelder, S., Designing Dual Inhibitors of Anaplastic Lymphoma Kinase (ALK) and Bromodomain-4 (BRD4) by Tuning Kinase Selectivity. J. Med. Chem. 2019, 62, 26182637.

40. Chen, L.; Yap, J. L.; Yoshioka, M.; Lanning, M. E.; Fountain, R. N.; Raje, M.; Scheenstra, J. A.; Strovel, J. W.; Fletcher, S., BRD4 Structure-Activity Relationships of Dual PLK1 Kinase/BRD4 Bromodomain Inhibitor BI-2536. ACS Med. Chem. Lett. 2015, 6, 764-769.

41. Scharow, A.; Knappe, D.; Reindl, W.; Hoffmann, R.; Berg, T., Development of Bifunctional Inhibitors of Polo-Like Kinase 1 with Low-Nanomolar Activities Against the PoloBox Domain. ChemBioChem 2016, 17, 759-767.

42. Kambe, T.; Correia, B. E.; Niphakis, M. J.; Cravatt, B. F. Mapping the Protein Interaction Landscape for Fully Functionalized Small-Molecule Probes in Human Cells. J. Am. Chem. Soc. 2014, 136, 10777-10782. 
TOC Graphic

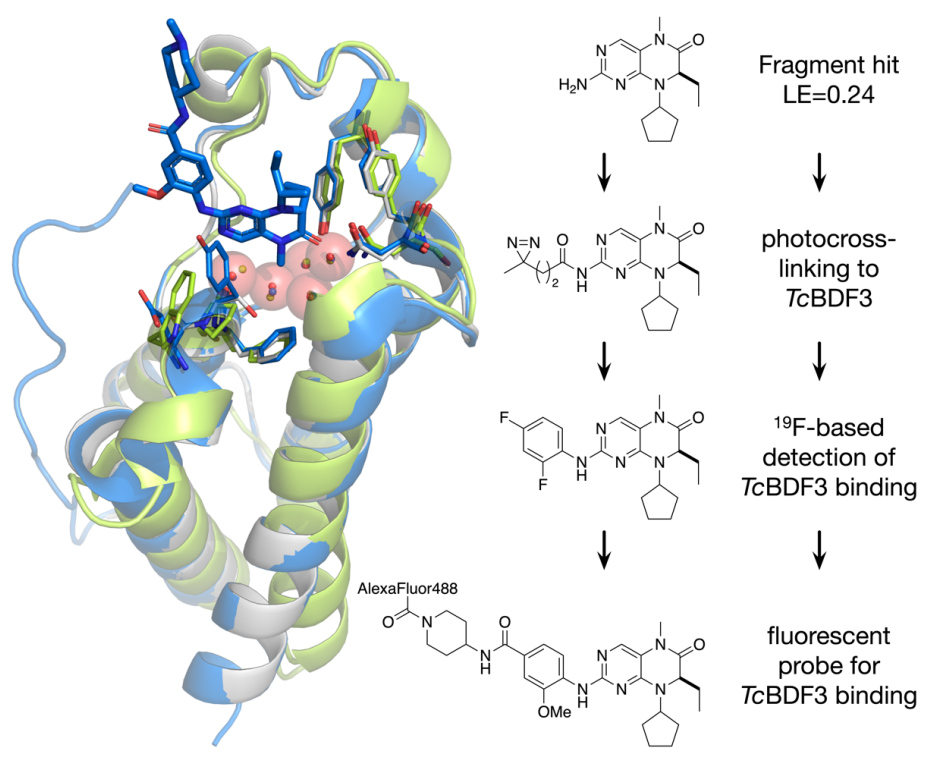

